$$
\text { UNIVERSIDADE DE SÃO PAULO }
$$

FACULDADE DE ODONTOLOGIA DE RIBEIRÃO PRETO

\begin{abstract}
Avaliação ex vivo da resistência à tração, de pinos metálicos em raízes fragilizadas tratadas com laser Er:YAG e reforçadas com resina composta.
\end{abstract}

Luciana Cavali Santello

Orientador: Prof. Dr. Luiz Pascoal Vansan

Ribeirão Preto 


\section{Avaliação ex vivo da resistência à tração, de pinos metálicos em raízes fragilizadas tratadas com laser Er:YAG e reforçadas com resina composta.}

Dissertação apresentada a Faculdade de Odontologia de Ribeirão Preto da Universidade de São Paulo para obtenção do título de Mestre em Ciências. Programa: Odontologia Restauradora Opção: Endodontia

Orientador: Prof. Dr. Luiz Pascoal Vansan

Ribeirão Preto 
Autorizo a reprodução e divulgação total ou parcial deste trabalho, por qualquer meio convencional ou eletrônico, para fins de estudo e pesquisa, desde que citada a fonte.

Assinatura do autor:

Data:

Ficha catalográfica

Santello, Luciana Cavali

Avaliação ex vivo da resistência à tração, de pinos metálicos em raízes fragilizadas tratadas com laser Er:YAG e reforçadas com resina composta. Ribeirão Preto, 2011.

79 p. : il. ; $30 \mathrm{~cm}$

Dissertação de Mestrado, apresentada à Faculdade de Odontologia de Ribeirão Preto/USP, Departamento de Odontologia Restauradora - Endodontia.

Orientador: Prof. Dr. Luiz Pascoal Vansan

1. Dentina do canal radicular reforçada. 2. Resina composta. 3. Laser Er:YAG. 4.. Resistência à tração. 
SANTELLO, L. C. Avaliação ex vivo da resistência à tração, de pinos metálicos em raízes fragilizadas tratadas com laser Er:YAG e reforçadas com resina composta, 2011, 79 p. Dissertação (Mestrado) - Faculdade de Odontologia de Ribeirão Preto, Universidade de São Paulo, Ribeirão Preto, 2011.

Aprovado em:

\section{Banca Examinadora}

Prof. Dr. Luiz Pascoal Vansan (orientador)

Instituição: Faculdade de Odontologia de Ribeirão Preto - USP

Julgamento:

Assinatura:

Prof.(a) Dr.(a):

Instituição:

Julgamento:

Assinatura:

Prof.(a) Dr.(a):

Instituição:

Julgamento:

Assinatura: 

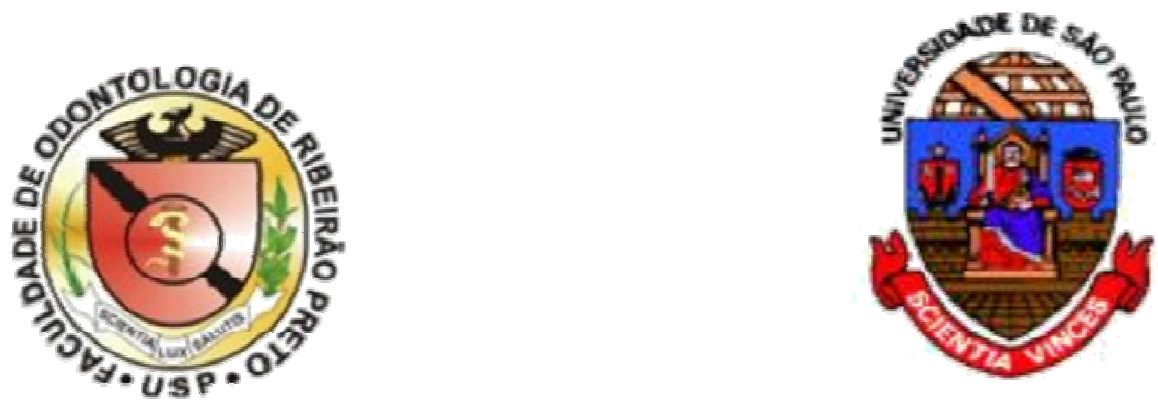

Este trabalho foi realizado no Laboratório de Pesquisa do Departamento de Odontologia Restauradora da Faculdade de Odontologia de Ribeirão Preto da Universidade de São Paulo. 


\section{DEDICATÓRIA}

Aos meus pais, José Claudio e Maria Lucia

Pelo apoio e amor incondicional. Vocês foram essenciais para mais esta conquista!

Aos meus irmãos, Marcelo e Claudia

Pelo amor e carinho que vocês têm para comigo. Pelo apoio e incentivo em todos os momentos da minha vida.

\section{À minha cunhada Andrea}

Por nos presentear com as minhas lindas sobrinhas Isabela e Luisa

Ao meu namorado, Jader

Pelo companheirismo durante esses anos.

À minha querida amiga Alessandra Marques Correa Afonso,

Pelo incentivo, apoio e ensinamentos sendo fundamental para o desenvolvimento desta pesquisa. 


\section{AGRADECIMENTOS ESPECIAIS}

Agradeço a Deus, pelas oportunidades concedidas e por estar presente em todos os momentos da minha caminhada, me concedendo sabedoria, paciência e força para atingir meus ideais. Obrigado, Senhor.

À minha família, e namorado que estiveram ao meu lado incondicionalmente, me apoiando e incentivando nos momentos difíceis e me auxiliando sempre que necessário para que eu pudesse realizar mais esta conquista. Amo vocês!

Ào meu orientador Prof. Dr. Luiz Pascoal Vansan, pela orientação repleta de ensinamentos e amizade. Pela confiança em mim depositada, paciência e disponibilidade em todos os momentos em que necessitei. Pessoa extremamente capaz, exemplo de dedicação ao ensino e a pesquisa. Você foi de extrema importância para o meu crescimento profissional! 


\section{AGRADECIMENTOS}

À Faculdade de Odontologia de Ribeirão Preto da Universidade de São Paulo, através de seu Diretor Prof. Dr. Osvaldo Luiz Bezzon.

À Coordenação do Curso de Pós-Graduação em Odontologia Restauradora da Faculdade de Odontologia de Ribeirão Preto da Universidade de São Paulo, na pessoa do Prof. Dr. Manoel Damião de Sousa Neto, cujo respeito e admiração crescem a cada dia, por toda dedicação na busca de nossos interesses.

Ao Prof. Dr. Marcelo Oliveira Mazetto, vice-coordenador do curso de PósGraduação em Odontologia Restauradora da Faculdade de Odontologia de Ribeirão Preto da Universidade de São Paulo.

Aos demais Professores do Departamento de Odontologia Restauradora, Prof. Dr. Jesus Djalma Pécora, Prof. Dr. Ricardo Gariba Silva, Prof. Dr. Ricardo Novak Savioli, Prof. Dr. Antonio Miranda da Cruz Filho, pelo empenho e satisfação ao transmitirem seus conhecimentos. 
Aos funcionários do Departamento de Odontologia Restauradora da Faculdade de Odontologia de Ribeirão Preto, Maria Amália, Maria Isabel, Rosângela, Luiza, Reginaldo, Patrícia.

Ao secretário do Curso de Pós-Graduação em Odontologia Restauradora da Faculdade de Odontologia de Ribeirão Preto, Carlos, por sua prontidão, dedicação e auxílio.

À professora Dra Yara Teresinha Corrêa Silva Sousa, coordenadora do programa de pós-graduação da Universidade de Ribeirão Preto, por permitir a utilização do Laboratório de Pesquisas da Universidade de Ribeirão Preto, bem como dos equipamentos de Laser Er:YAG e Máquina Universal de Ensaios.

Aos pós graduandos da Universidade de Ribeirão Preto - UNAERP, Alessandro Rogério Giovani, pela aplicação do laser, e Fuad Jacob Abi Rached Junior, pela realização do teste de Tração.

Ao Prof. Celso Bernardo de Souza Filho pelos ensinamentos de estatística.

Ao Professor Dr Edson Alfredo pelos ensinamentos de física, essenciais para os cálculos desta pesquisa.

Às funcionárias da Seção de Pós-Graduação da Faculdade de Odontologia de Ribeirão Preto da Universidade de São Paulo, Isabel e Regiane.

À Instituição $\boldsymbol{C N P q}$, pela bolsa de Mestrado.

Ao SESC - Serviço Social do Comércio, por permitir que eu concluísse mais essa etapa de aprendizado. 
Aos colegas do mestrado Juliane, Rayana, Josi, Marcus, Kleber e Samuel pela amizade, convivência e exemplo de dedicação às atividades de pesquisa.

Aos doutorandos Frank, Homero, Brufatto, Versiani, José Estevam, pelos ensinamentos, pela paciência, dedicação e por dividirem seus conhecimentos e experiências.

A todos que, de alguma forma colaboraram para que este trabalho se realizasse, meu especial agradecimento. 
"A mente que se abre a uma nova idéia jamais voltará ao seu tamanho original" Albert Einsten 


\section{RESUMO}

SANTELLO, L.C. Avaliação ex vivo da resistência à tração, de pinos metálicos em raízes fragilizadas tratadas com laser Er:YAG e reforçadas com resina composta. 79p. Dissertação (Mestrado) - Faculdade de Odontologia de Ribeirão Preto, Universidade de São Paulo, Ribeirão Preto, 2011.

O objetivo do estudo foi avaliar ex vivo a influência da aplicação do laser de Er:YAG na parede dentinária de raízes fragilizadas, reforçadas com resina composta. Cinquenta caninos superiores tiveram suas coroas removidas próximo da junção amelo-cementária e incluídas em bloco de resina acrílica. Após tratamento endodôntico foi realizada a fragilização das raízes. Os espécimes foram distribuídos aleatoriamente em 5 grupos ( $\mathrm{n}=10)$,: Grupo I - não irradiado, tratado com ácido fosfórico 37\%; Grupo II - irradiado com laser Er:YAG, 300mJ - $10 \mathrm{~Hz}$; Grupo III irradiado com laser Er:YAG, 300mJ - $10 \mathrm{~Hz}$ e tratado com ácido fosfórico $37 \%$ ;Grupo IV - irradiado com laser Er:YAG, $500 \mathrm{~mJ}$ - $10 \mathrm{~Hz}$; Grupo V - irradiado com laser Er:YAG, $500 \mathrm{~mJ}-10 \mathrm{~Hz}$ e tratado com ácido fosfórico $37 \%$. Todos os espécimes receberem reforço intra-radicular com resina composta, foto-polimerizada por meio de pino foto-transmissor. No espaço promovido por este pino foi cimentado o pino metálico pré-fabricado, com cimento resinoso auto-adesivo de dupla polimerização. Os espécimes foram submetidos ao teste de Tração na Máquina Universal de Ensaios - INSTRON 4444. Os maiores valores para o deslocamento foram atribuídos ao Grupo I, estatisticamente semelhante ao Grupo III. Entretanto o Grupo III ocupa uma posição intermediária, podendo pertencer também aos GruposIV e V que foram estatisticamente semelhantes entre si e ao grupo II.

Descritores: , dentina do canal radicular reforçada, resina composta, laser Er:YAG, resistência à tração. 


\begin{abstract}
SANTELLO, L.C. Tensile bond strength of metal posts after the application of Er:YAG laser treatment to the weakened root canal reinforced with composite resin. 79p. Dissertação (Mestrado) - Faculdade de Odontologia de Ribeirão Preto, Universidade de São Paulo, Ribeirão Preto, 2011.

The aim of this study was to assess ex vivo the effects of Er:YAG laser as dentin treatment of weakened root canal reinforced with composite resin. Fifty upper canines were decoronated at cementoenamel junction and the roots were embedded in acrylic resin. After the endodontic treatment the roots were weakened and the specimens were randomly assigned to five groups $(n=10)$ : Group I - unirradiated, treated with phosphoric acid 37\%; Group II - Er:YAG laser 300mJ - 10Hz; Group III - Er:YAG laser 300mJ - $10 \mathrm{~Hz}$, treated with phosphoric acid 37\%; Group IV Er:YAG laser $500 \mathrm{~mJ}-10 \mathrm{~Hz}$; Group V - Er:YAG laser $500 \mathrm{~mJ}-10 \mathrm{~Hz}$, treated with phosphoric acid $37 \%$. The intraradicular reinforcement was made in all specimens with composite resin using photo-transmitter post, which creates a space for the insertion of prefabricated metal post. The metal posts were inserted using a resin cement self-adhesive dual-cured. The tensile bond strength of specimens was tested in a universal testing machine - INSTRON 4444. The results showed that Group I was statistically similar to the Group III and presented the highest bond strength values. Group III also showed statistical similarity with Group IV and V, which were similar among them and the Group II.
\end{abstract}

Keywords: root canal dentin reinforced, resin composite, Er:YAG laser, tensile strength. 


\section{LISTA DE FIGURAS}

Figura 1 A) Remoção da coroa clinica, padronizando os espécimes em $17 \mathrm{~mm}$;

B) Matriz desmontável de alumínio;

C) Raiz incluída em resina com exceção do remanescente cervical de $3 \mathrm{~mm}$.

Figura 2 A) Brocas 730PM; 720PM e 718PM utilizadas no experimento;

B) Peça reta acoplada ao paralelômetro para fragilização de todas as amostras;

C) Vista aproximada do processo de fragilização.

Figura 3 A) Equipamento laser Opus 20;

B e C) Parâmetros utilizados.

Figura $4 \quad$ A) Fibra do Laser Er:YAG;

B) Irradiação Laser sendo aplicada no interior da dentina fragilizada.

Figura 5 A) Pino fototransmissor;

B) Aparelho fotopolimerizador Led Radii Plus de alta intensidade;

C) Polimerização da resina composta através do pino fototransmissor.

Figura 6 A) Pino metálico Reforpost II ํㅡ;

B) Aplicação do catalizador.

Figura 7 A) Corpos de Prova de um grupo (vista oclusal);

B) Vista palatina .

Figura 8 A) Máquina Universal de Ensaios - Instron 4444;

B) e C) Tracionamento do pino;

D) Pino metálico após deslocamento;

E) Conjunto de pino metálico e reforço radicular em resina composta após deslocamento.

Figura 9 Desenho esquemático da porção radicular, com área de fragilização (em preto) e reforço radicular (em azul), e suas respectivas medidas. 


\section{LISTA DE TABELAS}

Tabela 1 Parâmetros utilizados para a irradiação dos espécimes.

Tabela 2 Valores da força de tração, em kN, necessária para 0 deslocamento dos retentores intra radiculares.

Tabela 3 Valores em MPa da força de Tensão após cálculo da área de deslocamento.

Tabela 4 Cálculos para avaliação de normalidade na amostra.

Tabela 5 Teste Tukey-Kramer de Comparações Múltiplas. 


\section{LISTA DE ABREVIATURAS - SIGLAS E SÍMBOLOS}

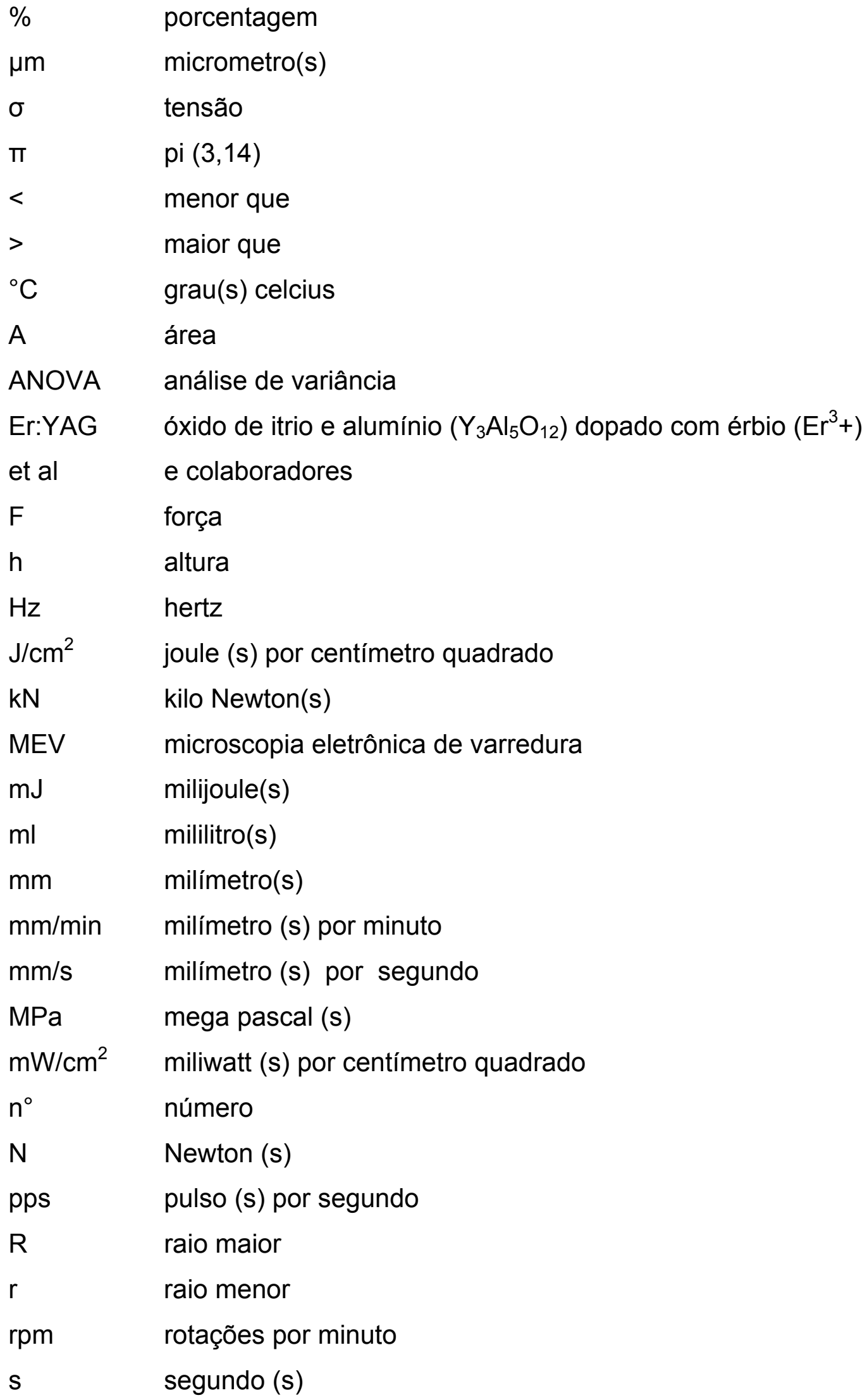


SD

desvio padrão

vs

versus

W

watt(s) 
RESUMO

ABSTRACT

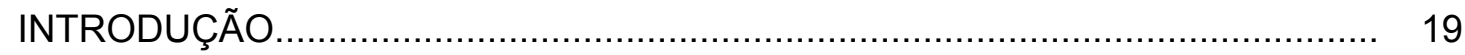

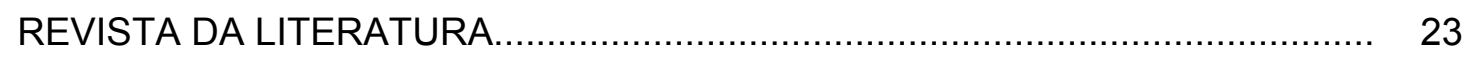

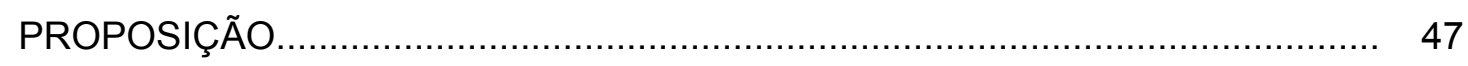

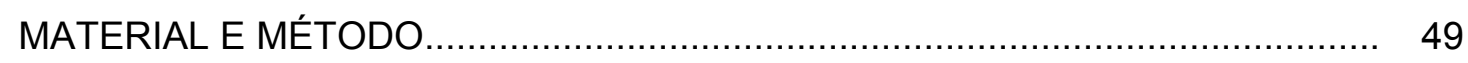

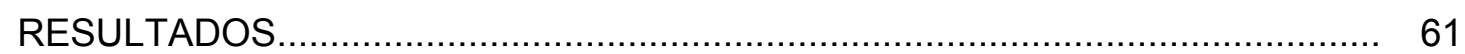

DISCUSSÃO

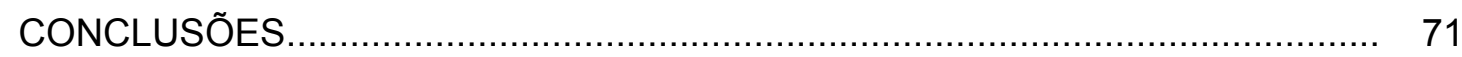

REFERÊNCIAS BIBLIOGRÁFICAS.................................................... 73

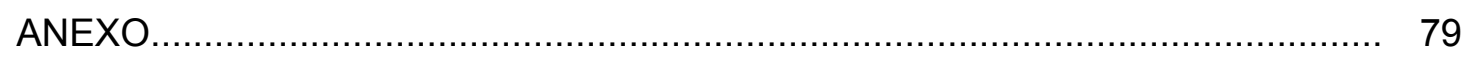




\section{INTRODUÇÃO}

Na clínica diária, muitas vezes nos deparamos com raízes que, por estarem expostas ao meio bucal, encontram-se cariadas. Com a remoção deste tecido, restam apenas raízes com paredes fragilizadas, com pouco ou nenhum remanescente coronário.

A máxima preservação da estrutura dental é o fator mais importante a ser levado em consideração para restauração de um dente tratado endodonticamente; porém, em algumas situações, há a perda de quantidade exagerada da estrutura dentinária radicular, necessitando reforçar este remanescente, na busca de reconstruir o elemento dental.

Vários são os estudos no intuito de encontrar um material que melhor preencha o lugar da dentina perdida, promovendo um reforço intra radicular, seja pelo uso de resina (LUI, 1994; MARTINS, 1995; DE PAULA et al., 1998; MIRANZI et al., 2001; HOU et al., 2003), ou cimento de ionômero de vidro (MCLEAN, 1990; LUI, 1992; MARTINS, 1995).

As resinas compostas fotopolimerizáveis, agregadas à técnica do condicionamento ácido do esmalte e dentina, constituem um dos materiais mais 
utilizados em restaurações nas últimas décadas (OLIVEIRA-JUNIOR, 1997). Na literatura, vários pesquisadores preconizaram seu uso como material de preenchimento e reforço intra-radicular em raízes fragilizadas, como forma de aumentar sua resistência à fratura (GODDER et al., 1994; LUI, 1994; MARTINS, 1995; SAUPE et al., 1996; OLIVEIRA JUNIOR, 1997; TJAN et al., 1997; DE PAULA et al., 1998; MIRANZI et al., 2001; COELHO, 2003; HOU et al., 2003; MARCHI et al., 2003; ARUNPRADITKUL et al., 2004; SUMPANSIRIKUL et al., 2004).

Quando do uso da resina fotopolimerizável para promover tal reforço, devemos utilizar um sistema adesivo, que favorece a união do compósito à dentina (GONÇALVES, 2006), entretanto, alguns fatores podem interferir neste mecanismo, como a camada de smear layer e o cimento endodôntico utilizado.

Os insucessos na retenção adicional, promovida pelos sistemas adesivos, ocorrem devido a uma conjunção de fatores que envolvem todos os passos da técnica operatória, do preparo do canal radicular até a polimerização final do material resinoso (CARVALHO et al., 2004).

Com a finalidade de favorecer a adesão da resina, o preparo do canal radicular e sua obturação devem ser metas almejadas pelo Cirurgião Dentista, principalmente em se tratando de dentes que receberão núcleos de preenchimento.

De acordo com Steele (1973), a dentina de um dente tratado endodonticamente torna-se friável, por perder sua elasticidade, e a fratura ocorre geralmente próxima da região cervical. Este autor concluiu que o combate dos efeitos do estresse oclusal em dentes com tratamento endodôntico pode ser melhorado com o uso de reforço intra-radicular, confeccionado com resina composta, promovendo maior ancoragem da dentina friável.

Desta forma, é importante o desenvolvimento de novas técnicas, protocolos e materiais como forma de ampliar as opções restauradoras de reforço radicular, proporcionando melhor aproveitamento do remanescente dentário e possibilitando a recuperação de dentes extremamente destruídos em uma única sessão (MOOSAVI et al., 2008).

Com o desenvolvimento dos pinos fototransmissores, o uso da resina composta tornou-se viável para o reforço das paredes do canal radicular, pois além de realizar a fotopolimerização em um nível maior de profundidade, promove nova 
configuração morfológica e adequa o diâmetro do canal ao de um pino metálico fundido ou pré-fabricado (FREEDMAN et al., 1994; MALLMANN et al., 2007).

Atualmente, além do ácido etilenodiaminotetracético (EDTA), outros meios estão sendo pesquisados com aplicabilidade no tratamento das paredes dentinárias para remoção da smear layer, como é o caso da radiação LASER, cujo nome é um acrônimo da língua inglesa "Light Amplification by Stimulated Emission of Radiation", que significa: amplificação da luz por emissão estimulada de radiação.

A utilização do laser de Er:YAG na remoção da smear layer e abertura dos canalículos foi pesquisada por Takeda et al., 1998, possibilitando uma maior penetração dos cimentos endodônticos no interior dos canalículos, além de promover uma maior superfície de adesão, com consequente melhoria desta propriedade.

Além da remoção da smear layer, trabalhos foram realizados utilizando o laser Er:YAG como complemento, com o objetivo de reduzir o numero de microorganismos dentro do sistema de canais radiculares (MORITZ et al., 1999, PERIN et al., 2004; BITTER et al., 2008), melhorar a retenção de pinos à dentina radicular tratada com laser (ALFREDO et al., 2005), aumentar a permeabilidade dentinária (BRUGNERA JÚNIOR et al., 2003). Há ainda, o que revela que a irradiação laser cria uma camada que afeta adversalmente a adesão da resina à dentina radicular (CEBALLOS et al., 2002).

Outro estudo com diferentes parâmetros de laser (MARRACINI et al. 2006) foi desenvolvido para avaliar a força de adesão da resina composta aos tecidos dentários duros após irradiação com laser Er:YAG. Segundo os autores, uma das variáveis que pode influenciar a aderência entre tecidos e resina composta é o aumento da temperatura produzido por um laser sobre estes tecidos durante a irradiação. Este aumento de temperatura pode alterar a matriz orgânica e como consequência o entrelaçamento de tecido e material restaurador pode interferir negativamente na eficiência da adesão.

Diante do exposto, torna-se importante estudar a aplicabilidade do laser Er:YAG com diferentes parâmetros, associados ou não ao condicionamento ácido, 
22 | Introdução

se este é capaz de interferir na adesão entre a dentina radicular fragilizada e o reforço radicular em resina composta fotopolimerizável. 


\section{REVISTA DA LITERATURA}

De acordo com Steele (1973), a dentina de um dente tratado endodonticamente torna-se friável, perdendo sua elasticidade. Nesse caso, um dente despolpado torna-se mais susceptível à fratura, que geralmente ocorre próximo da região cervical. Mencionou, assim, algumas vantagens do reforço de um núcleo confeccionado com resina composta como: 1- Custo mínimo quando comparado ao núcleo fundido em ouro; 2- Menor possibilidade de perfuração da raiz; 3- Prevenção da pressão hidrostática do núcleo sobre as paredes do conduto no momento da cimentação, entre outras. Concluiu que o combate dos efeitos do estresse oclusal em dentes com tratamento endodôntico pode ser minimizado com o uso de reforço intra-radicular confeccionado com resina composta, provendo maior ancoragem da dentina friável.

Mclean (1990) relatou que os Cimentos de ionômero Cermet são significativamente mais resistentes à abrasão do que os cimentos de ionômero de vidro, sendo amplamente aceitos como materiais de núcleo e forramento, podendo fortalecer os dentes.

Lui (1992), em um relato de caso utilizou o cimento de vidro Cermet, devido suas propriedades melhoradas em comparação com os cimentos de ionômero de 
vidro convencionais. Sendo também aceito como substituto dentinário para fortalecer os dentes. Neste trabalho, uma aplicação adicional para cimento de ionômero Cermet, o reforço de raízes enfraquecidas tratadas endodonticamente é sugerido.

Freedman et al. (1994) apresentaram um caso clínico de reabilitação intraradicular. Comentaram que a importância na colocação de contenções intraradiculares está na mudança do conceito de sua capacidade em fortalecer a estrutura do dente para sua capacidade em proporcionar retenção adicional e resistência ao deslocamento do material, sem induzir estresse funcional. Um pino que não se ajusta bem no interior do canal radicular pode resultar numa menor retenção da restauração protética e possivelmente numa fratura do remanescente dental. Isso acontece particularmente com sistemas de núcleos pré-fabricados, cuja forma geralmente apresenta aproximação muito distante do espaço intra-radicular. Nesse caso, o uso de cimentos convencionais, para preenchimento de grandes espaços não é devidamente indicado, pois funciona melhor quando se interpõem em finíssimas espessuras. Assim, o uso de resinas compostas e adesivos dentinários para preenchimento do canal radicular, associado ao sistema de pinos plásticos fototransmissores, promove um efeito superior na resistência à compressão e são menos solúveis aos fluídos bucais. Ressaltaram que paredes finas ou raízes frágeis não são mais prognósticos de dentes condenados à extração. Diante do caso apresentado, concluíram que a reabilitação intra-radicular com o sistema utilizado dá oportunidade ao clínico de criar uma estreita geometria para os pinos em todo e qualquer dente.

Godder et al. (1994) descreveram uma técnica para reabilitação e reforço, com resina composta fotopolimerizável, de paredes finas de raízes tratadas endodonticamente. Segundo os autores, restaurações com núcleos fundidos ou préfabricados diretamente sobre essas raízes podem criar efeito de cunha que pode levar à fratura da raiz quando submetida à carga funcional. Além disso, núcleos muito largos criariam uma interface gengival que interferiria no resultado estético da restauração final pelo efeito sombra. Comentaram que alguns clínicos têm preconizado o uso de contenção intra-radicular construída inteiramente com resina composta auto polimerizável, mas que este material tem tido suas limitações pela polimerização e endurecimento prematuros à sua adaptação nas paredes da raiz.

Conforme Lui (1994), a introdução de compósitos fotopolimerizáveis tem sido defendida para reforçar raízes debilitadas, entretanto, o controle é difícil em 
função da polimerização no interior da raiz. O autor preconiza a utilização de dispositivo que transmite a luz no interior do conduto, polimerizando a resina com mais eficiência. Conclui que o uso combinado de adesivo, compósito e dispositivo polimerizador permite tratamento reabilitador conservativo com técnica simples, para dentes teoricamente perdidos.

Martins (1995) avaliou a resistência à fratura de dentes unirradiculares, com raízes debilitadas preenchidas com materiais adesivos e com núcleos fundidos cimentados, nas seguintes condições: controle positivo (preparo convencional), controle negativo (raízes debilitadas), raízes preenchidas com ionômero fotoativado, raízes preenchidas com sistema adesivo/compósito. Os materiais testados foram: ionômero tipo II modificado (Chelon-Silver) ionômero tipo III (Ketac-Bond), ionômero foto ativado (Vitremer), compósitos (Herculite XRV e Z100). Após a remoção das coroas clinicas dos dentes, as raízes eram preparadas para receberem os devidos tratamentos. Confeccionados os padrões em resina acrílica, os mesmos eram incluídos e fundidos. Obtidos os núcleos em liga de $\mathrm{Cu}-\mathrm{Al}$, estes eram adaptados e cimentados no interior do canal. Os corpos de prova eram então submetidos a carregamento em máquina de ensaio universal até a fratura da raiz. Concluiu que, entre os materiais testados, o compósito Z100 teve melhor desempenho que todos os demais e inclusive quanto ao controle positivo; o ionômero Vitremer, o compósito XRV e o Chelon-Silver apresentaram resultados semelhantes entre si e ao controle positivo; o ionômero Ketac-Bond teve comportamento desfavorável em relação a todos os outros e semelhante ao controle negativo.

De acordo com Saupe et al. (1996), a reabilitação de um dente despolpado é criticamente importante para assegurar o sucesso do tratamento restaurador póstratamento endodôntico. A estrutura residual que permanece é uma fina parede de conduto que pode comprometer o prognóstico, a longo prazo, da restauração do dente. Tradicionalmente, dois sistemas de núcleos com diferentes características têm sido reconhecidos. No primeiro, o núcleo fundido reproduz a morfologia do espaço do conduto radicular. O segundo incorpora o uso de materiais adesivos e técnicas de reforço intra-radicular quando suas raízes apresentam paredes finas e, nesse caso, a dimensão interna do remanescente da estrutura da raiz foi reforçada com uma resina aderida à dentina. Nesse sentido, os autores investigaram, in vitro, a validade do potencial de reforço intra-radicular. O comportamento de dois diferentes sistemas de núcleos foi avaliado e envolveram: 1) núcleo fundido fixado 
com cimento adesivo resinoso; 2) reforço intra-radicular com resina seguido pela fixação de um núcleo fundido com cimento resinoso. Para o estudo, foram selecionados 40 incisivos centrais superiores hígidos com semelhança de forma, tamanho e anatomia radicular. As coroas foram seccionadas, perpendicularmente ao longo eixo da raiz, ao nível de 1 a $2 \mathrm{~mm}$ da junção amelo-cementária, de forma a deixar o comprimento da raiz em torno de $14 \mathrm{~mm}$. O conduto foi instrumentado de acordo com a técnica convencional até a lima 35 e a irrigação foi realizada com hipoclorito de sódio a $2,5 \%$. Os canais foram secados com cones de papel e obturados por condensação lateral de guta-percha com cone 35. O cimento utilizado para o tratamento endodôntico não continha eugenol. A guta-percha foi removida de cada conduto, de forma a manter o material obturador até $4 \mathrm{~mm}$ do ápice. Para simular um comprometimento clínico extensivo, o espaço do conduto radicular foi preparado com $10 \mathrm{~mm}$ de comprimento, sendo que os $2 \mathrm{~mm}$ próximos do material obturador, ou seja, ao nível do assentamento apical do núcleo, seguiram a anatomia da raiz e os $8 \mathrm{~mm}$ acima, foram preparados com espessura das paredes de dentina radicular de 0,5 a $0,75 \mathrm{~mm}$. As 40 amostras foram divididas em dois principais grupos, com 20 cada. Cada grupo foi subdividido em dois grupos de 10, totalizando 4 grupos: Grupo A- núcleo cimentado em raiz sem bisel; Grupo B- raiz reforçada com resina e núcleo cimentado em raiz sem bisel; Grupo $\mathrm{C}$ - núcleo cimentado englobando bisel de $2 \mathrm{~mm}$ no contorno da raiz; Grupo D- raiz reforçada com resina e núcleo cimentado englobando bisel de $2 \mathrm{~mm}$ no contorno da raiz. Segundo os autores, o bisel foi incluído para avaliar seus efeitos sobre a resistência à fratura sob simulação de carga mastigatória. Todos os núcleos foram fundidos em ouro tipo III, tendo a parte coronária, altura de $8 \mathrm{~mm}$. A carga foi mantida numa velocidade de 2 $\mathrm{mm} / \mathrm{min}$ até o momento da fratura. Os resultados mostraram que a resistência à fratura do grupo de raízes reforçadas com resina foi significantemente maior que a dos grupos que receberam núcleo sem reforço. Em relação à inclusão do bisel no preparo da raiz, não houve diferenças significantes quando comparado com o grupo de raízes que não receberam bisel.

Segundo Oliveira Junior (1997), as resinas fotopolimerizáveis vêm sendo muito empregadas como material de reforço intra-radicular. Cita algumas vantagens do sistema de pinos plásticos fototransmissores, como: fácil, rápido e seguro; diminui o risco de fratura da raiz; permite o reforço de estruturas fragilizadas. Comenta que o ponto alto desse sistema de ancoragem é o seu componente foto-transmissor. 
Além de polimerizar integralmente a resina no interior do conduto, cria o espaço adequado para acomodar passivamente o pino pré-fabricado.

Tjan et al. (1997) avaliaram as propriedades retentivas de núcleos cimentados em condutos radiculares previamente reforçados com resina fotopolimerizável por meio de sistema de pinos plásticos transmissores de luz, com e sem adesivo dentinário, e compararam com o sistema convencional de núcleos fundidos e cimentados com cimento fosfato de zinco. Para o estudo, foram selecionados 30 pré-molares inferiores com forma e tamanho semelhantes. Todos os dentes tiveram suas coroas secionadas a aproximadamente $2 \mathrm{~mm}$ da junção amelo-cementária. Em cada dente, o espaço para o núcleo foi preparado com $7 \mathrm{~mm}$ de profundidade e 3,5 mm de diâmetro. Os dentes foram separados em três grupos de 10 amostras: 1- Confecção de núcleo metálico fundido e cimentação com fosfato de zinco; 2- Reforço das paredes com resina composta fotopolimerizável e núcleo de aço-inoxidável pré-fabricado cimentado com cimento resinoso quimicamente ativado; 3- Reforço das paredes com resina fotopolimerizável como no grupo 2, mas as paredes das raízes receberam condicionamento ácido e adesivo dentinário. Os resultados indicaram um aumento da retenção em aproximadamente $300 \%$ quando comparada com o mesmo sistema de reforço sem adesivo dentinário que, por sua vez, teve sua propriedade retentiva diminuída para $72 \%$ daquela obtida com cimentação com fosfato de zinco.

De Paula et al. (1998) analisaram radiograficamente a espessura de resina composta fotopolimerizável utilizada na reconstrução da parede dentinária intraradicular. Avaliaram o espaço intra-radicular desde o estágio inicial do dente até o preparo radicular final para a confecção de núcleo metálico fundido. Todos os recursos dos adesivos de última geração foram utilizados, bem como os princípios dos materiais plásticos restauradores. Os autores concluíram ser uma alternativa excelente para o reforço intra-radicular em casos de raízes frágeis. O controle radiográfico mostrou diferentes espessuras de resina fotopolimerizável na porção intra-radicular, atuando como reforço das paredes laterais de raiz enfraquecida.

Takeda et al. (1998) avaliaram a eficácia do Laser Er:YAG na remoção de detritos e smear layer das paredes do canal preparado. Trinta e seis dentes incisivos humanos extraídos foram divididos em três grupos. Grupo I (G1) grupo controle, não foram submetidos ao laser. Os dentes do grupo 2 (G2) e grupo 3 foram irradiados por Laser Er:YAG em diferentes potencias de $1 \mathrm{~W}$ e $2 \mathrm{~W}$. Os dentes foram 
seccionados ao meio e preparados para estudo em microscópio de luz estereoscópica e Microscopia Eletrônica de Varredura (MEV). Amostras do Grupo controle mostraram uma quantidade de detritos e smear layer obscurecendo os túbulos dentinários em todos os níveis dos canais. As paredes do canal radicular irradiada pelo laser Er: YAG estavam livres de detritos, com uma camada de esfregaço evaporou-se e abriu os túbulos dentinários. As análises estatísticas mostraram diferenças significativas $(p<0,01)$ na camada de limpeza do esfregaço entre G1 e G2, e G1 e G3. No entanto, não houve diferença estatisticamente significativa entre G2 e G3 na limpeza do meio e um terço apical dos canais radiculares. Os resultados mostraram que laser Er: YAG é eficaz na remoção de detritos e smear layer das paredes do canal radicular.

Takeda et al. (1998) investigaram as alterações morfológicas e a capacidade de remoção da camada de smear das paredes dos canais radiculares do laser Er:YAG. Trinta e seis incisivos inferiores humanos tiveram suas coroas seccionadas e os canais radiculares ampliados até o instrumento de calibre \#40 por meio da técnica step back, utilizando $3 \mathrm{~mL}$ de $\mathrm{NaOCl} 5,25 \%$ e $\mathrm{H}_{2} \mathrm{O}_{2}$ alternadamente. As raízes foram separadas no sentido longitudinal e as hemi-secções distribuídas aleatoriamente em três grupos $(n=12)$ : Grupo 1- não irradiado (controle); Grupo 2superfície da parede do canal radicular irradiada com laser Er:YAG, com potência de $1 \mathrm{~W}$, energia de pulso de $1 \mathrm{~mJ}, 10 \mathrm{~Hz}$ de frequência durante 3 segundos e Grupo 3utilizou os mesmos parâmetros do grupo 3 e aplicação por 5 segundos. A irradiação foi aplicada em direção perpendicular a uma distância de $2 \mathrm{~cm}$ em relação à superfície do canal, mantendo esta superfície umedecida. Os espécimes foram desidratados em série ascendentes de solução de etanol e submetidos à análise em microscopia eletrônica de varredura (MEV). O grupo controle apresentou espessa camada de smear, obstruindo a entrada dos túbulos dentinários, enquanto que as superfícies irradiadas apresentaram-se livres de camada de smear e túbulos dentinários abertos. De acordo com os autores, a irradiação com laser Er:YAG apresenta eficiente capacidade de limpeza sobre as paredes de canais radiculares instrumentados.

Cohen et al. (1999) compararam o sistema de pino pré-fabricado Flexi-Post (pino metálico rosqueável e haste com fenda) e o C-Post (pino reforçado de fibra de carbono) quanto à resistência, retenção e propriedades fotoelásticas, quando submetidos a duas condições de cargas: vertical e oblíqua com ângulo de $26^{\circ}$. Os 
resultados mostraram que o sistema Flexi-Post, em relação ao C-Post, apresentou aumento significante na força necessária para que ocorresse a falha de retenção durante o tracionamento dos pinos. No teste fotoelástico, momento em que os pinos não estão sendo submetidos a cargas, tanto o Flexi-Post quanto o C-Post apresentaram um stress mínimo; entretanto, o Flexi-Post apresentou concentração simétrica de stress na região coronária, quando submetido a cargas verticais e oblíquas e o C-Post apresentou concentração assimétrica de força na região apical. Os autores concluíram que o sistema Flexi-Post é mais favorável, pois mostrou nivelamento simétrico do stress e maior retenção comparada ao C-Post.

Moritz et al. (1999) compararam a eficácia antibacteriana dos lasers Nd:YAG, Ho:YAG e Er:YAG em canais radiculares infectados. Quarenta dentes extraídos, tratados endodonticamente foram inoculados com uma suspensão de Escherichia coli e Enterococcus faecalis e depois irradiados com as configurações de energia padronizados. A eficácia de desinfecção de cada laser foi comprovado por exame microbiológico clássico. Este artigo destaca que os três lasers diminuíram substancialmente a população de bactérias com apenas diferenças mínimas na sua eficácia bactericida. De 1,5W, os melhores resultados foram obtidos pelo laser Er: YAG alcançaram uma média de eliminação bacteriana de 99,64\%, seguido pelo Nd: YAG laser $(99,16 \%)$, eo Ho: YAG laser $(99,05 \%)$. Os achados indicaram que os três lasers agem como bactericidas fortemente eficazes sem causar aumentos de temperatura desfavoráveis com os parâmetros utilizados, podendo ser considerados uma ferramenta valiosa para o tatamento endodôntico.

Miranzi et al. (2001) avaliaram comparativamente, a resistência sob força de compressão oblíqua, de raízes tratadas endodonticamente com reduzida espessura de dentina, após cimentação de núcleos metálicos fundidos e sistemas de pinos préfabricados associados a mecanismos de fototransmissão. Concluíram que, baseados na metodologia empregada, as forças de compressão requeridas até o momento da fratura foram maiores para o grupo de raízes que receberam os pinos pré-fabricados do que para o grupo de raízes com núcleo metálico fundido.

Segundo Ceballos et al. (2002), o laser de Er:YAG têm sido utilizado para melhorar as propriedades adesivas da dentina. Neste estudo foi avaliado se a adesão da dentina é afetada pelo condicionado com laser Er:YAG. Sessenta terceiros molares humanos foram obtidos, trinta foram seccionados abaixo da junção dentina-esmalte, lixados, para obterem superfícies uniformes de dentina superficial, 
os trinta dentes restantes foram seccionados $1,1 \pm 0,1 \mathrm{~mm}$ abaixo do nível original para expor a dentina profunda. Superfícies de dentina superficial e profunda foram distribuídas aleatoriamente em três grupos experimentais: Grupo I - ataque ácido com ácido fosfórico gel 35\% por 15 segundos e lavadas por 10 seg. Grupo II irradiados com laser Er:YAG modo pulsante, $2 \mathrm{~Hz}$ e $180 \mathrm{~mJ}$, sob refrigeração a água. Grupo III - Irradiação laser e ataque ácido. Adesivo dentinário Single Bond e resina composta fotopolimerizável Z100 foram colados às superfícies preparadas. Foi realizado teste de cisalhamento nas amostras, e analisados por microscopia eletrônica de transmissão. Os resultados indicaram que a resistência ao cisalhamento não foi significativamente influenciada pela profundidade da dentina $(p=0,91)$. No entanto, o condicionamento ácido sozinho, obteve valores de resistência ao cisalhamento, significativamente maiores que os obtidos com a ablação a laser sozinho ou a combinação laser e ácido. O laser Er:YAG criou uma camada que afeta negativamente a adesão à dentina, por isso não constitui uma alternativa para o condicionamento ácido convencional.

Pécora et al. (2002) descreveram uma técnica de preparo biomecânico dos canais radiculares, utilizando instrumentos rotatórios de níquel-titânio. Aspectos importantes na utilização desses instrumentos são discutidos, e uma sequência de preparo é proposta, objetivando-se a redução do risco de fraturas dos mesmos.

Sasaki et al. (2002) compararam, in vitro, através da MEV, a morfologia do cemento e dentina radicular após irradiação com laser Er:YAG, laser de CO2 e superfícies não irradiadas. O laser Er:YAG (2,94 $\mu \mathrm{m})$ foi utilizado com energia de 40 $\mathrm{mJ}$, frequência de $10 \mathrm{~Hz}$ com uma fibra de diâmetro de $600 \mu \mathrm{m}$, angulada em $30^{\circ}$ com a superfície, com e sem refrigeração, durante 20 segundos. A irradiação com laser de CO2 (10,6 $\mu \mathrm{m})$ foi realizada com 0,5 W, sem refrigeração, em modo focado, com distância de aproximadamente $5 \mathrm{~mm}$ da superfície, durante 30 segundos. As superfícies irradiadas foram analisadas em aumentos de 3000 e 5000 X. Diante dos resultados, os autores concluíram que o cemento e dentina irradiado com o laser Er:YAG apresentaram aspectos distintos de micro-rugosidades, entretanto em maiores aumentos, ambos, cemento e dentina, apresentaram características similares, e ainda, o laser de CO2 promoveu derretimento e formação de crateras nas superfícies. Além disto, o uso de irrigação com água durante a irradiação minimizou os efeitos térmicos sobre as superfícies, resultando em superfície mais limpa e menos porosa. 
Brugnera Junior et al. (2003) avaliaram a remoção da smear layer nos terços apical e médio, usando cinco diferentes técnicas de cinemática. Trinta caninos humanos foram instrumentados usando hipoclorito de sódio a 2,5\% com uma irrigação final com água destilada, e divididos aleatoriamente em 6 grupos diferentes. O laser Er:YAG foi aplicado em cinco grupos com fibra óptica 50/28 com $250 \mathrm{~mJ}$ input $112 \mathrm{~mJ}$ output, $10 \mathrm{~Hz}$ a $1 \mathrm{~mm}$ do ápice com técnicas de cinemática distintas. O grupo 6 não recebeu irradiação a laser. Duas fotos de cada canal foram obtidas (terço médio e apical), e analisada a quantidade da smear layer no microscópio eletrônico de varredura. Os resultados demonstraram diferenças estatísticas $(p<0,05)$ entre os tratamentos e diferenças significativas $(p<0,01)$ entre os terços radiculares Os autores concluíram que todas as técnicas cinemáticas produziram os mesmos resultados na remoção da smear layer e o terço médio apresentou menos smear layer que o terço apical depois da irradiação com o laser Er:YAG.

Coelho (2003) analisou a influência da espessura dentinária, após fragilização da estrutura radicular, utilizando sistema adesivo e resina composta para reconstrução das paredes, através de elementos finitos, para analisar a distribuição das tensões em incisivo central superior restaurado com diferentes sistemas de pinos intra-radiculares pré-fabricados e núcleos metálicos fundidos. Os sistemas de pinos e o dente hígido foram confeccionados nos seguintes modelos: 1- dente hígido; 2- sistema de pino metálico fundido com reconstrução da estrutura axial dentária; 3- sistema de pino metálico fundido sem reconstrução da estrutura axial dentária; 4- sistema de pino de aço-inoxidável; 5- sistema de pino de titânio; 6sistema de pino de zircônio; 7- sistema de pino de fibra de carbono; 8- sistema de pino de fibra de vidro. O autor concluiu que: 1- restauração do incisivo central superior com sistema de pinos radiculares cilíndrico metálico fundido, aço-inoxidável, zircônio, fibra de vidro e fibra de carbono alteraram a distribuição de tensões na dentina radicular, em relação ao dente hígido. As restaurações com sistemas de pinos de fibra de carbono e de vidro apresentaram distribuição de tensões mais uniforme na dentina radicular. A reconstrução das paredes dentinárias com sistema adesivo e resina composta promoveu melhor distribuição de tensões. Os grupos do sistema de pino de aço-inoxidável, zircônio, metálico fundido sem reconstrução das paredes dentinárias com sistema adesivo e resina composta apresentaram maior concentração de tensões do que os grupos de sistemas de pinos de fibra de carbono 
e vidro. O grupo do sistema de pino metálico fundido sem reconstrução das paredes dentinárias com sistema adesivo e resina composta apresentou a maior concentração de tensões.

Hou et al. (2003) avaliaram a resistência à fratura de raízes fragilizadas restauradas com contenções intra-radiculares. Trinta e dois dentes foram divididos em quatro grupos, sendo o primeiro (G1) constituído de raízes normais. No segundo grupo (G2), as raízes foram enfraquecidas e reabilitadas com resina composta fotopolimerizável. No terceiro (G3), as raízes foram enfraquecidas e reabilitadas com amálgama e o quarto grupo (G4) foi composto por raízes enfraquecidas e não reabilitadas. Todos os grupos tiveram suas raízes restauradas com núcleo fundido. Carga compressiva foi aplicada num ângulo de $90^{\circ}$ em relação ao longo eixo do dente, numa velocidade de $1 \mathrm{~mm} / \mathrm{min}$, até o momento da fratura. As médias de força no grupo G1, G2, G3 e G4 foram respectivamente 202,92N, 194,60N, 146,89N e $142,09 \mathrm{~N}$, respectivamente sendo a carga necessária para a fratura de raízes normais, significativamente maior que a carga necessária para a fratura de raízes não tratadas. Não houve diferença significante entre os grupos de raízes reabilitadas, e também destas com o grupo de raízes normais. Os autores concluíram que a reabilitação de raízes fragilizadas com resina composta fotopolimerizável não somente muda a forma do conduto radicular, mas também aumenta a resistência à fratura da raiz.

Lee et al. (2003) investigaram a fase de composição e as alterações morfológicas da dentina irradiada com laser Er:YAG com ou sem spray de água, por meio de raios- $X$ difratômetro (XRD), espectroscopia de infravermelho transformada de Fourier (FTIR), e Microscopia Eletrônica de Varredura (MEV). As energias de irradiação foram 300-700 mJ/pulse-10 pps-10 s. Após a exposição ao laser Er: YAG, dentina não mostrou mudanças de fase no difratômetro de raios-X. Na análise de infravermelho transformada de Fourier, duas bandas de absorção em 2200 e 2015 cm-1 pode ser rastreada em dentina tratada com laser Er: YAG com as energias de irradiação além dos 300 pps mJ/pulse-10 s-10 e sem spray de água. Microscopia eletrônica de varredura revelou que a energia do laser de 500 mJ/pulse-10 pps-10 s foi suficiente para fusão e recristalização dos cristais de dentina. Portanto, spray de água é importante para reduzir o efeito térmico do laser Er:YAG.

Marchi et al. (2003) avaliaram a resistência à fratura de raízes de dentes bovinos enfraquecidas experimentalmente e reforçadas internamente com dois 
diferentes tipos de cimentos resinosos, em combinação com sistemas de pinos préfabricados e foram comparadas com raízes intactas. Setenta e cinco incisivos mandibulares foram selecionados com diâmetros semelhantes. Sessenta dentes foram internamente preparados de forma a simular enfraquecimento, sendo um grupo de raízes preenchidas com cimento resinoso e o outro grupo, preenchidas com cimento resinoso modificado com ionômero de vidro. Os corpos-de-prova foram submetidos ao teste de resistência à fratura com aplicação de uma força compressiva num ângulo de $135^{\circ}$ em relação ao longo eixo do dente. As raízes restauradas com cimento resinoso demonstraram resistência à fratura significantemente menor quando comparadas com as restauradas com cimento resinoso modificada com ionômero de vidro. Os autores concluíram que nenhum dos materiais envolvidos foi capaz de promover aumento da resistência à fratura em comparação com o grupo de raízes não enfraquecidas.

Segundo Arunpraditkul et al. (2004), estudos preliminares mostraram que canais radiculares fragilizados, reforçados com resina composta, podem reduzir estresse na dentina radicular. Além disso, o uso de núcleos de fibra de carbono, como contenção intra-radicular, mostrou-se mais favorável à distribuição do estresse sobre esses dentes. Comentaram também que o efeito do material restaurador final, ou seja, da coroa, não pode ser negligenciado. Nesse sentido, investigaram a distribuição do estresse em dentes com raízes fragilizadas restaurados com coroas com coping de alumina e coroas metalocerâmicas. Concluíram que as coroas com coping de alumina podem reduzir o estresse ocorrido ao longo da dentina radicular quando restauradas com núcleos de ouro ou fibra de carbono. O uso de coroas metalocerâmicas com núcleos de ouro pode resultar em maior estresse na porção apical do núcleo.

Carvalho et al. (2004) analisaram, por meio de revisão de literatura, os fundamentos que orientam a correta aplicação clínica dos sistemas adesivos. Todos os tópicos apresentados no trabalho são importantes, porém o mais relevante para o estudo em questão é a cimentação de núcleos ou pinos intra-radiculares, onde os autores enumeram os fatores a serem considerados para cimentação de pinos: 1limpeza do canal não deve ser feita com soluções oxidantes (hipoclorito de sódio ou peróxido de hidrogênio); 2- o controle da umidade pode ser eficiente na região cervical, mas deficiente na região apical; 3- durante a aplicação do adesivo, o controle da sua espessura, evaporação do solvente e brilho da superfície pode ser 
eficiente na região cervical, mas haverá tendência de acúmulo de adesivo na região apical. O excesso de adesivo na região apical dificulta a evaporação do solvente e compromete sua polimerização. Devido ao limitado acesso, a foto-ativação do adesivo ficará comprometida, principalmente na região apical. $\mathrm{O}$ acesso da luz ficará ainda mais limitado durante a foto-ativação do cimento, determinando polimerização eficiente somente na região cervical. Mesmo com emprego de cimentos de polimerização dual, a porção do cimento localizada na região cervical se polimerizará somente pela reação química, deixando essa porção do cimento susceptível a adversidades do contato com eventual acidez do adesivo. Os autores concluíram que o futuro da odontologia adesiva é desafiador e atraente. As pesquisas caminham em direção à compreensão de pormenores da relação entre polímeros e estrutura dental. Embora a odontologia adesiva tenha relacionado de forma irreversível os conceitos restauradores, a confiabilidade dos sistemas adesivos não permite, ainda, que princípios biológicos e mecânicos sejam esquecidos.

Coelho (2004) avaliou o efeito da aplicação dos lasers Er:YAG e Nd:YAG, em diferentes parâmetros, nas superfícies dentinárias internas da região cervical de dentes humanos sobre a adesividade de um cimento obturador à base de resina epóxi pelo método do push-out. Quarenta e cinco caninos superiores foram seccionados transversalmente na junção amelocementária e a $8 \mathrm{~mm}$ da mesma em sentido apical, criando um cilindro de raiz que foi incluído em resina acrílica autopolimerizável. Com auxílio de uma broca tronco-cônica foram preparados os canais radiculares dos corpos de prova. Os mesmos foram divididos aleatoriamente em 9 grupos. No grupo I, a dentina foi tratada com $2 \mathrm{~mL}$ de EDTAC por 5 minutos. Do grupo II ao $\mathrm{V}$, a dentina foi tratada com laser Er:YAG com os seguintes parâmetros: $8 \mathrm{~Hz}$ e $200 \mathrm{~mJ}$; $8 \mathrm{~Hz}$ e $400 \mathrm{~mJ} ; 16 \mathrm{~Hz}$ e $200 \mathrm{~mJ} ; 16 \mathrm{~Hz}$ e $400 \mathrm{~mJ}$, respectivamente. Do grupo $\mathrm{VI}$ ao IX, a dentina foi tratada com o laser Nd:YAG com os seguintes parâmetros: $10 \mathrm{~Hz}$ e 1W; $10 \mathrm{~Hz}$ e 2W; $15 \mathrm{~Hz}$ e 1 W; $15 \mathrm{~Hz}$ e 2 W, respectivamente. Os condutos foram preenchidos com cimento à base de resina epóxi e submetidos ao teste de tração na Máquina Universal de Ensaios. A análise estatística dos resultados evidenciou diferença ao nível de $1 \%$ entre os tratamentos com os lasers Er:YAG e Nd:YAG com maiores frequências e o EDTAC. Concluiu-se que o aumento da frequência, independente do aumento da potência, dos lasers 
Er:YAG e Nd:YAG, provocou aumento da adesividade do cimento obturador à base de resina epóxi em relação ao grupo tratado com EDTAC.

Perin et al. (2004) avaliaram ação antibacteriana do laser Er:YAG em canais radiculares infectados. Quarenta e oito incisivos centrais superiores foram utilizados. Após o preparo do canal, os dentes foram autoclavados e divididos em quatro grupos: (1) dentes não tratados (grupo controle); (2) dentes tratados com NaOCl; (3) dentes irradiados com laser Er:YAG (7Hz, 100mJ, 80 pulsos/canal, 11 segundos) para o comprimento de trabalho; (4) irradiados semelhante ao grupo 3, mas $3 \mathrm{~mm}$ aquém do ápice. Os canais dos grupos 2,3 e 4 foram inoculados com 4 bactérias subtillus Bacillus, Enterococcus faecalis, Pseudomonas aeruginosa e Staphylococcus aureus, juntamente com a Candida albicans, e mantidos por 24 horas a $37^{\circ} \mathrm{C}$. Todas as suspensões foram ajustadas ao tubo 2 da escala de MacFarland. O material intracanal foi coletado com cones de papel estéreis, que foram colocados nos canais por 5 min e depois imersos em $5 \mathrm{ml}$ de meio BHI. Estes foram, então semeados em ágar e corados pelo método de Gram. As soluções de $\mathrm{NaOCl}$ e irradiação laser Er:YAG no comprimento de trabalho foram eficazes contra todas os cinco microorganismos, no entanto, $70 \%$ dos espécimes irradiados $3 \mathrm{~mm}$ aquém do ápice permaneceram infectados.

Sumpansirikul e Salimee (2004) investigaram a resistência à fratura e o modo de fratura de dentes com raízes fragilizadas. Quarenta incisivos centrais superiores tiveram as raízes fragilizadas e restauradas com quatro diferentes métodos, sendo cada um composto por dez dentes e comparados com um grupo controle (G1), também composto por dez dentes com raízes normais restauradas com núcleo metálico fundido. No grupo G2, as raízes fragilizadas receberam núcleo metálico fundido. No G3, as raízes receberam reforço com resina composta e núcleo metálico fundido. No G4, reforço com resina composta e núcleo de aço-inoxidável com reconstrução coronária em resina. No G5, reforço com resina composta e núcleo de fibra de carbono com reconstrução coronária em resina composta. Todos os núcleos foram fixados com cimento resinoso. A carga aplicada em $130^{\circ}$ na superfície lingual da porção coronária das contenções intra-radiculares. O grupo G1 foi significantemente mais resistente à fratura. O G3 teve resistência à fratura significantemente maior que o G2. Os grupos G1, G2 e G3 (com núcleo metálico fundido) foram significantemente mais resistente à fratura que os grupos G4 e G5 (núcleo de aço-inoxidável e fibra de carbono, respectivamente). Os grupos G4 e G5 
não tiveram diferença entre si na força de fratura, a qual ocorreu na reconstrução coronária. Os autores concluíram que as restaurações com núcleos metálicos fundidos foram mais resistentes, mas resultaram em fratura das raízes, enquanto as restaurações com núcleos pré-fabricados foram menos resistentes, mas resultaram em fratura da reconstrução coronária de resina composta.

Alfredo et al. 2005, avaliaram a retenção de pinos à dentina tratada com EDTA e irradiada com laser Er:YAG, e cimentadas com cimento resinoso e cimento de fosfato de zinco. Quarenta e oito amostras foram divididas em três grupos. G1 (controle) - superfície de dentina sem tratamento, irrigada com água destilada e deionizada; G2 - NaOCl 1\% + EDTA 17\%; e G3 - água e laser Er:YAG $(8 \mathrm{~Hz}$, $200 \mathrm{~mJ}, 60 \mathrm{~J}, 300$ pulsos). Cada grupo foi subdividido em 2 subgrupos dependendo do cimento usado: Panávia $F$ ou Fosfato de zinco. Todos os espécimes foram submetidos à carga de tração na Máquina Universal Instron 4444 a $0,5 \mathrm{~mm} / \mathrm{min}$. Os resultados mostraram não haver diferença significativa $(p>0,01)$ entre os tratamentos da parede dentinária com $\mathrm{NaOCl} 1 \%$ + EDTA 17\% (6.80 MPa) e água + laser Er:YAG (6.81 MPa), independente do cimento utilizado, no entanto, estes foram estatisticamente diferentes $(p<0,01)$ do grupo controle que apresentaram os menores valores $(4,82 \mathrm{MPa})$. Cimentação com Panavia $F$ e fosfato de zinco apresentaram resultados semelhantes de resistência adesiva $(p>0,05)$. Os autores concluíram que o tratamento prévio das paredes de dentina com $\mathrm{NaOCl} 1 \%+$ EDTA $17 \%$ ou Er:YAG + água favoreceu a retenção do pino com cimento resinoso e com cimento de fosfato de zinco.

Fonseca et al (2006) avaliaram a retenção de pinos intra-radiculares variando a técnica de aplicação do agente adesivo e do cimento resinoso dual no espaço protético preparado para a recepção do pino. Sessenta caninos superiores tratados endodonticamente tiveram as coroas descartadas e as raízes incluídas em resina acrílica. Os espaços protéticos foram preparados com broca de Largo acionada por micromotor acoplado a um paralelômetro, a fim de manter constantes 0 comprimento e diâmetro dos pinos intra-radiculares e o paralelismo dos preparos após a fundição. Os pinos foram divididos aleatoriamente em 2 grupos $(n=30)$ conforme a técnica de aplicação do agente adesivo: com "microbrush" ou com pincel (controle). Cada grupo foi subdividido em três subgrupos $(n=10)$ segundo a técnica de aplicação do agente cimentante: com o próprio pino, com broca de lentulo previamente ao posicionamento do pino ou associação dos dois modos. Após 72 
horas do processo de cimentação, os pinos foram tracionados pela Máquina Universal de Ensaios (Instron 4444) à velocidade de $1 \mathrm{~mm} / \mathrm{min}$. Os resultados mostraram diferença estatística significante $(p<0,001)$ entre as técnicas de aplicação do agente adesivo com "microbrush" (0,1740 \pm 0,04 kN) e pincel $(0,1369 \pm$ $0,04 \mathrm{kN}$ ). Em relação à técnica de aplicação do cimento no interior do espaço protético, a da associação entre lentulo e pino $(0,1787 \pm 0,03 \mathrm{kN})$ foi estatisticamente diferente $(p<0,001)$ das do lentulo $(0,1461 \pm 0,065 \mathrm{kN})$ e do pino $(0,1416 \pm 0,03 \mathrm{kN})$ isoladamente. As interações entre as técnicas de aplicação do agente adesivo e do agente cimentante apresentaram diferença estatística $(p<0,001)$. Os autores concluíram que as interações entre as técnicas de aplicação do agente adesivo com "microbrush" e aplicação do agente cimentante com lentulo $(0,1961 \pm 0,04$ kN) e com lentulo e pino associados $(0,1911 \pm 0,02 \mathrm{kN})$ propiciaram os maiores valores da força de tração.

Braga et al. (2006) avaliaram, in vitro, a resistência ao deslocamento vertical de retentores intra-radiculares de fibra de vidro e metálicos fundidos, com diferentes comprimentos $(6,8$, e $10 \mathrm{~mm})$, por meio de força de tração. A amostra constou de sessenta caninos superiores hígidos que tiveram suas coroas seccionadas e seus canais radiculares tratados endodonticamente. As raízes foram incluídas em resina acrílica, constituindo os corpos de prova, que foram distribuídos em 3 grupos, em função do comprimento do preparo do conduto $\mathrm{e}$, consequentemente, do comprimento do pino cimentado (6, 8 e 10mm). Cada grupo foi dividido em 2 subgrupos, de acordo com o tipo de pino cimentado: subgrupo A1 - pinos de fibra de vidro com $6 \mathrm{~mm}$ de comprimento; $\mathrm{A} 2$ - pinos metálicos fundidos com $6 \mathrm{~mm}$; B1 pinos de fibra de vidro com $8 \mathrm{~mm}$; B2 - pinos metálicos fundidos com $8 \mathrm{~mm}$; C1 pinos de fibra de vidro com $10 \mathrm{~mm}$ e C2 - pinos metálicos fundidos com $10 \mathrm{~mm}$. Os preparos dos condutos foram realizados com as brocas do kit Fibrekor Post, em baixa rotação, acopladas a um paralelômetro. Os pinos metálicos fundidos foram obtidos pela moldagem dos condutos com resina acrílica ativada quimicamente, seguida da fundição. Todos os pinos (metálicos fundidos e de fibra de vidro) foram cimentados com cimento resinoso Panavia F. Os corpos de prova foram submetidos ao teste de tração na Máquina Universal de Ensaios Instron 4444 a uma velocidade de $1 \mathrm{~mm} / \mathrm{min}$. Os dados foram submetidos à análise de variância, que não acusou diferença estatística significante $(p>0,05)$ entre os tipos de pinos utilizados. Com relação aos comprimentos dos pinos, houve diferença significante entre eles 
$(p<0,01)$ e o teste de tukey evidenciou que os pinos de 6 e $10 \mathrm{~mm}$ foram diferentes entre si e os de $8 \mathrm{~mm}$ apresentaram valores intermediários, não havendo diferença significante quando comparados aos de 6 e $10 \mathrm{~mm}$. Concluiu-se que o tipo de pino, metálico fundido ou de fibra de vidro, não influenciou nos valores de retenção. Entretanto, o comprimento teve influência, sendo que pinos de $10 \mathrm{~mm}$ de comprimento promoveram maiores valores de retenção quando comparados aos de $6 \mathrm{~mm}$, porém, os pinos de $8 \mathrm{~mm}$ de comprimento mostraram comportamento semelhante aos pinos de 6 e $10 \mathrm{~mm}$ de comprimento.

Gonçalves et al. (2006) avaliaram a resistência à fratura de raízes fragilizadas, após reforço com diferentes resinas compostas fotopolimerizáveis, em conjunto com pinos pré fabricados e pinos metálicos fundidos. Quarenta e oito corpos de prova foram divididos em 6 grupos: Grupo I - raízes preparadas e pinos metálicos fundidos; Grupo II - raízes fragilizadas e pinos metálicos fundidos; Grupos III, IV, V e VI - raízes fragilizadas, reforçadas com resinas compostas fotopolimerizáveis (Filtec Supreme, Tetric Ceram, Z100 e Renew), com auxílio de pinos Luminex e pinos pré-fabricados de titânio. Todos os pinos foram cimentados com cimento resinoso e submetidos à força de compressão oblíqua em ângulo de $135^{\circ} \mathrm{em}$ relação ao longo eixo das raízes na Máquina Universal de Ensaios Instron 4444 , à velocidade de $1 \mathrm{~mm} / \mathrm{min}$, até a fratura das raízes. A análise de variância não evidenciou diferença significante entre os Grupos III, IV e VI entre si e ao Grupo I, quanto à força de resistência à fratura. O Grupo II apresentou os menores valores de força para que ocorressem as fraturas, comparativamente aos demais. Concluíram que o uso de resinas compostas como reforço em raízes fragilizadas promoveu efetivo e significante aumento na resistência à fratura.

Marracini et al. (2006) avaliaram, por meio do teste de tração e MEV, a adesão da resina composta ao esmalte e dentina coronária previamente irradiados com os lasers Er:YAG e CO2. Coroas de 156 incisivos superiores bovinos foram distribuídas aleatoriamente em seis grupos, de acordo com o tratamento utilizado: GI. Controle: esmalte com condicionamento ácido; GIl. Controle: dentina com condicionamento ácido sem irradiação; GIII. Esmalte com irradiação do laser de CO2 (150 mJ; $20 \mathrm{~Hz} ; 212,2 \mathrm{~J} / \mathrm{cm} 2 ; 3 \mathrm{~W}$ ) e condicionamento ácido; GIV. Dentina com irradiação do laser de CO2 (150 mJ; $20 \mathrm{~Hz} ; 212,2 \mathrm{~J} / \mathrm{cm} 2 ; 3 \mathrm{~W}$ ) e condicionamento ácido; GV. Esmalte com irradiação do laser Er:YAG (80 mJ; $2 \mathrm{~Hz} ; 25,7 \mathrm{~J} / \mathrm{cm} 2 ; 0,16$ W) e condicionamento ácido; GVI . Dentina com irradiação do laser Er:YAG (80 mJ; 
$2 \mathrm{~Hz} ; 25,7 \mathrm{~J} / \mathrm{cm} 2 ; 0,16 \mathrm{~W})$ e condicionamento ácido. Os resultados evidenciaram que o tratamento do esmalte e da dentina com o laser Er:YAG propiciaram os maiores valores na força de adesão, semelhante aos obtidos com condicionamento ácido, enquanto que o tratamento com o laser de $\mathrm{CO} 2$ produziram os menores valores de adesão tanto no esmalte quanto na dentina. A análise em MEV mostrou que os espécimes irradiados com o laser de $\mathrm{CO} 2$ e condicionados com ácido apresentaram desmineralização interprismática no esmalte e exposição dos túbulos na dentina, que resultou em aspecto semelhante aos padrões de condicionamento ácido no esmalte e dentina. Por outro lado, os espécimes irradiados com o laser Er:YAG e submetidos ao condicionamento ácido apresentaram superfície menos irregular tanto no esmalte quando na dentina, que apresentou alguns túbulos dentinários expostos. Segundo os autores, o aumento da temperatura pelos lasers promove desnaturação da matriz colágena superficial e sub-superficial da dentina. Considerando que o colágeno desempenha importante papel na união dentina/resina composta, e que o condicionamento ácido remove apenas $7 \mu \mathrm{m}$ desta superfície, mantendo as alterações subsuperficiais, os valores de adesão dentina/resina composta foram menores nos espécimes irradiados com o $\mathrm{CO} 2$ devido às maiores alterações no substrato causadas pelo maior aumento da temperatura.

Mallmann et al. (2007) avaliaram a resistência à microtração de dois sistemas adesivos à dentina radicular e dois diferentes pinos de fibra reforçados. Quarenta dentes unirradiculares foram instrumentados e preparados para receber pino de fibra translúcida (Post Light - PL) ou opaco ( Aesthetic Post - AP). Dois sistemas adesivos foram utilizados, Scotchbond Multi-Purpose Plus (SBMP) (autopolimerizavel) como grupo de controle, e Single Bond (SB) (foto ativado). Dentes foram divididos em 4 grupos $(n=10)$. G1 - SBMP1LP; G2 - SBMP1AP; G3 SB1LP; G4 - SB1AP. Após a cimentação dos pinos, as raízes foram seccionadas perpendicularmente em $1 \mathrm{~mm}$ de espessura, que foram cortadas para obter espécimes em forma de halteres. Os espécimes foram divididos em 3 regiões: cervical $(\mathrm{C})$, médio $(\mathrm{M})$ e apical $(\mathrm{A})$. Para determinar a resistência de união, a área de ligação de cada amostra foi calculada, e as amostras foram unidas a um dispositivo para teste de força de micro tração a uma velocidade de $1 \mathrm{~mm} / \mathrm{min}$. Os dados foram analisados usando 3-way análise de variância e teste de Tukey $(\alpha=$. 05). Espécimes fraturados foram examinados sob microscópio estereoscópico 325 
para determinar o modo de fratura. Resultados: houve diferença significativa apenas entre as regiões de dentina radicular $(P<0,001)$. O terço cervical $(9,16 \pm 1,18 \mathrm{Mpa})$ apresentou maior valor médio de resistência de união, especialmente para SBMP.

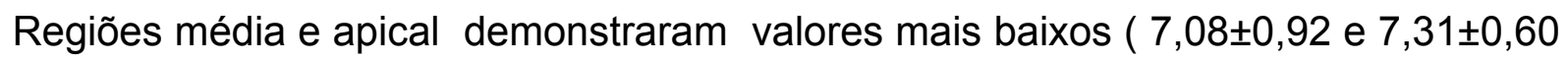
Mpa, respectivamente). Adesivo e pino não demonstraram significância. Também, nenhuma interação foi significante. Nenhuma fratura coesiva com cimento resinoso, pino reforçado com fibra, ou dentina radicular foram identificadas. Ambos os sistemas adesivos demonstraram confiável adesão quando usados com pino translúcido ou opaco.

Bitter et al. (2008), avaliaram os efeitos de agentes antibacterianos (laser Érbio: ítrio-alumínio-granada [Er: YAG] ou ozônio gasoso) destinados para desinfetar canais radiculares, na resistência de união de pinos de fibra em comparação com canais que foram irrigados usando clorexidina ( $\mathrm{CHX})$. Cento e quarenta e quatro dentes humanos anteriores foram divididos em três grupos $(n=48)$; a instrumentação do canal radicular foi realizada, e o pré tratamento antimicrobiano foi realizado da seguinte forma: grupo controle: CHX, grupo 2: laser Er:YAG, e grupo 3: ozônio gasoso. Em todos os grupos, pinos de fibra foram inseridos usando Panavia F 2.0 (Kuraray, Osaka, Japão), Variolink II (Ivoclar Vivadent, Schaan, Liechtenstein), RelyX Unicem (3M Espe, Seefeld, Alemanha), ou Ketac Cem (3M Espe) (n=12 cada). Força de adesão, no teste push-out, na dentina radicular foram afetadas pelo tipo de agente cimentante, mas não pelo pré-tratamento antimicrobiano. No entanto, interações significativas entre o agente cimentante e o pré tratamento podem ser observados, e a adesão do cimento resinoso auto-adesivo RelyX Unicem foi reduzida significativamente após o uso do ozônio gasoso.

Moosavi et al. (2008) compararam a resistência à fratura de dentes anteriores tratados endodonticamente com suas raízes reforçadas com três diferentes métodos. Quarenta incisivos centrais superiores humanos foram divididos aleatoriamente em quatro grupos $(n=10)$. As coroas foram removidas a $2 \mathrm{~mm}$ da junção amelo cementaria (CEJ). Após tratamento do canal radicular, espécimes foram divididos em três grupos. No primeiro, segundo e terceiro grupos os canais foram reforçados com resina composta RCO (Clearfil DC Core Automix), REF (dois reforpins), e RCE (cimento resinoso) (Panavia F 2.0), respectivamente. No quarto grupo (DEN) espécimes não foram reforçados. O mesmo tamanho de pinos de fibra reforçados com resina (FRC) foram cimentados com cimento resinoso (Panavia $F$ 
2.0) em todos os grupos . Após cimentação dos pinos e restauração do dente com construção do núcleo (Clearfil Photo Core), as raízes foram incluídas em blocos de resina acrílica $1 \mathrm{~mm}$ da CEJ. As amostras foram levadas à Máquina de ensaio Instron com velocidade de $0,5 \mathrm{~mm} / \mathrm{min}$ no ângulo de $45^{\circ}$ do longo eixo do dente na superfície palatina até ocorrer à fratura. Dados foram analisados usando Kruskal-Wallis, MannWhitney e Teste Qui-Quadrado $(p=0,05)$. Diferenças significativas foram encontradas entre todos os grupos $(p<0,05)$ com exceção dos grupos RCO e REF. O menor valor $230(130) \mathrm{N}$ e o maior valor médio 830 (220) N foram mostrados na resistência à fratura dos grupos RCE e DEN, respectivamente. Reforpin, pode ser usado como alternativa à resina composta para reforço interno de raízes enfraquecidas de acordo com os autores. Para o reforço dos canais, pinos de fibra junto com Reforpin ou resina composta provaram ter maior resistência à fratura do que cimento resinoso.

Para Sasaki et al. (2008), o laser Er:YAG tem sido estudado como uma ferramenta potencial para a odontologia restauradora, devido à sua capacidade de remover seletivamente tecido duro oral, com mínimo ou nenhum dano térmico aos tecidos vizinhos. Os autores avaliaram in vitro a resistência à tração (TBS) de um sistema de resina composta/ adesiva em superfície de esmalte humano tratado com ácido fosfórico a $37 \%$, laser Er:YAG $(\lambda=2,94 \mu \mathrm{m})$ com uma energia total de $16 \mathrm{~J}$ (80mJ/ pulso, $2 \mathrm{~Hz}, 200$ pulsos) e laser Er:YAG seguido por ataque ácido. Análise das superfícies tratadas foi realizada por MEV para avaliar as diferenças morfológicas entre os grupos. TBS (em MPa) foram os seguintes : laser Er:YAG + ácido (11.7MPa)> ácido (8,2MPa)> laser Er:YAG $(6,1 \mathrm{MPa})$ com o grupo tratado com laser + ácido sendo significativamente melhor que os demais grupos ( $p=0,0006$ e $p=0,00019$, respectivamente). Os grupos tratados com ácido e laser sozinhos só foram significativamente diferentes entre si $(p=0,0003)$. A análise morfológica revelou na MEV mudanças que corroboram com os resultados da TBS, sugerindo que as diferenças médias na TBS entre os grupos estão relacionados aos diferentes condicionamentos produzidos por cada tipo de tratamento de superfície. As conclusões deste estudo indicam que a associação entre laser Er:YAG e ácido fosfórico pode ser usado como um recurso valioso para aumentar a resistência de união de esmalte preparado à laser.

Teixeira et al. (2008) avaliaram a dureza Vickers (VHN) de uma resina composta após reforço radicular, de acordo com o tempo de exposição à luz, a região de reforço intra canal e distância lateral do pino de fibra de transmissão de 
luz. Utilizaram quarenta e cinco raízes de $17 \mathrm{~mm}$. Vinte e quatro horas após obturação os canais foram esvaziados a uma profundidade de $12 \mathrm{~mm}$ e as raízes foram fragilizadas para produzir um espaço de $1 \mathrm{~mm}$ entre o pino de fibra e as paredes do canal. As raízes foram restauradas com resina composta, que foi foto ativado por 40s (G1, controle) 80s (G2) ou 120s (G3). Vinte e quatro horas após a cimentação, os espécimes foram seccionados transversalmente em três faixas de profundidade de 2, 6 e $10 \mathrm{~mm}$, correspondente às regiões coronal, média e apical da raiz reforçada. Os autores concluíram que a dureza da resina composta foi significativamente menor em regiões mais profundas do reforço da raiz e em áreas laterais mais distantes do pino foto transmissor. O tempo de exposição de luz de 120s proporcionou maior dureza do que os tempos mais curtos (40 e $80 \mathrm{~s}$ ).

Giachetti et al. (2009) compararam, por meio do teste de push out, a força interfacial de dois cimentos resinosos dual e um cimento fotopolimerizável quando usado para cimentação de pino de fibra translúcida. Foram selecionados trinta e nove dentes pré-molares humanos extraídos, de canal único, tratados endodonticamente. Pinos de fibra translúcida (RelyX Fiber Post) foram cimentados no canal radicular por meio de três sistemas de cimentação resinosa $(n=13)$. Técnica de cura dual (DC): os espécimes foram tratados com Excite DSC e RelyX ARC, que foram polimerizados simultaneamente por 60s. Técnica auto-adesiva de cura dual (SADC): os espécimes foram tratados com RelyX Unicem, que foi fotopolimerizado por 60s. Técnica Fotopolimerizável (LC): os espécimes foram tratados com Excite DSC e Tetric Flow, que foram simultaneamente fotopolimerizados por 60s. Os espécimes foram seccionados transversalmente em seis fatias, a fim de realizar o teste push-out. Os resultados não mostraram diferença estatística entre os DC e LC, em cada região. Com a técnica LC, valores de resistência de união foram menores na região apical do que os registrados nas regiões coronal e médio. Nas regiões coronal e médio, os valores de resistência de união para a técnica da SADC foram menores do que os resultados ao utilizar as outras duas técnicas. Na região apical, não houve diferença significativa na resistência de união entre as técnicas de cimentação testados. Os autores concluíram que a força interfacial entre cimento fotopolimerizável e canal radicular é equivalente à força interfacial entre cimento de cura dual e canal radicular.

Teixeira et al. 2009, avaliaram a resistência de união de pinos de fibra translúcida em dentina radicular enfraquecida experimentalmente, restaurada com 
resina composta e polimerizadas com o tempo de exposição de luz diferentes. Raízes de 60 incisivos superiores foram utilizados. Vinte e quatro horas após a obturação, o material de preenchimento foi removido em $12 \mathrm{~mm}$, e quatro grupos foram formados aleatoriamente. Em três grupos, dentina radicular foi reduzida para produzir um espaço entre pino de fibra e parede do canal. No grupo controle, as raízes não foram experimentalmente enfraquecidas. As raízes foram restauradas com resina composta, que foi ativada pela luz através de pinos translúcidos por 40 , 80 e 120 segundos. Pinos foram cimentados, e depois de 24 horas, todas as raízes foram seccionadas transversalmente nas regiões coronal, média e apical, produzindo corpos de prova de $1 \mathrm{~mm}$ de espessura. Teste push-out foi realizado, e modo de falha foram observados. A análise quantitativa mostrou diferença estatística significativa apenas entre os grupos $(P<0,001)$. Comparando os grupos enfraquecidos/ restaurados, o tempo de exposição à luz não influenciou os resultados. No geral, as falhas adesivas ocorreram com maior freqüência do que outros tipos de falhas. Falhas coesivas ocorreram apenas nas raízes enfraquecidas/restauradas. Os autores concluíram que a restauração intracanal com resina composta e pinos de fibra translúcida promoveram igual ou superior força de adesão que o grupo controle, independente do tempo de exposição da luz utilizada para polimerização.

Garcia et al., 2010 avaliaram a resistência de união do cimento RelyX Unicem (RX), em comparação com Cement Post (CP), nos terços cervical, médio e apical de dentina radicular irradiada com laser Diodo 980-nm. Quarenta caninos superiores foram separados em quatro grupos iguais de acordo com o cimento utilizado e do tratamento de superfície a laser. Grupo RX/ laser irradiação (LI); Grupo RX/ sem irradiação (NI); Grupo CP/LI; Grupo CP/NI. Dois slices (2 mm de espessura) de cada terço radicular foram submetidos ao teste de push-out para avaliar resistência de união do cimento à dentina radicular. Os dados obtidos foram submetidos à ANOVA e a análise de fratura foi realizada por MEV. O tipo de cimento, bem como irradiação laser nos diferentes terços do canal radicular, tiveram valores significativamente diferentes de resistência adesiva $(p<0,05)$. LI promoveu aumento na resistência de união de $\mathrm{RX}$ em todos os terços radiculares $(p<0,05)$. Para todos os grupos, resistência de união no terço cervical foi maior, seguido pelos terços médio e apical $(p<0,05)$. Quando os cimentos foram comparados, $R X$ sempre apresentou maior resistência em comparação com CP, independente da aplicação 
do laser $(p<0,05)$. Análise da fratura mostrou predominância de falhas mistas para $\mathrm{RX}$ e de falha adesiva entre dentina e cimento para CP, independente da aplicação do laser. LI promoveu aumento na resistência de união do cimento resinoso autoadesivo para dentina radicular.

Zorba et al. (2010) avaliaram os efeitos de diferentes fotopolimerizadores e dois agentes de cimentação na resistência de união de pino de fibra translúcida. Trinta raízes de incisivos foram tratadas endodonticamente. Espaços para pinos foram preparados, e a smear layer foi removida. Pinos FRC Postec Plus foram cimentados com um cimento auto condicionante (Panavia F2.0) ou um cimento auto adesivo (Maxcem). Agentes cimentantes foram então ativados por luz halógena, LED ou arco de plasma. Raízes/ pinos cimentados foram seccionados transversalmente de coronal para apical. Teste push-out foram realizados, e os dados foram analisados usando analise de variância e Teste de Tukey. Resultados da resistência de união foram significantes pelo tipo de agente cimentante $(P<05)$ e região da raiz $(P<.05) O$ tipo de fonte de luz utilizado não afetou a resistência de união. Cimento resinoso auto-adesivo proporcionou maior resistência de união que o cimento autocondicionante quando smear layer foi removida antes da cimentação do pino. Resistência de união da porção apical da raiz foi significativamente menor que na região coronal. O uso de diferentes fotopolimerizadores para fotopolimerização de cimento resinoso de cura dual não afetou a retenção do pino de fibra, como resultado da limitada capacidade de transmissão de luz deste pino.

Bell Ronnlof et al. (2011) avaliaram a capacidade de carga e micro tensão de incisivos fragilizados restaurados com pinos de titânio pré fabricados e pinos reforçado por fibra. As coroas dos incisivos humanos foram cortadas e preparo para o pino foi realizado. As raízes foram divididas em grupos: (1) pinos de titânio préfabricados, (2) pinos pré-fabricados de fibra de carbono reforçado, (3) pinos formados por fibra de vidro, e (4) formadas individualmente (split) de fibra de vidro. Os pinos foram cimentados e as coroas foram feitas. Incisivos humanos intactos foram usados como referência. As raízes foram incluídas em resina acrílica e armazenadas à temperatura ambiente em água. Carga estática foi aplicada em um ângulo de $45^{\circ}$ usando uma máquina universal de ensaios. Em metade dos espécimes micro tensão foi medida com extensômetro e uma análise de emissão acústica foi realizada. Modo de falha também foi avaliado. Resultados: o grupo com pinos de titânio mostrou maior número de falhas desfavoráveis em relação ao grupo 
com pinos de fibra. Pinos reforçados com fibra as falhas podem ser frequentemente favoráveis em comparação com pinos de titânio, que clinicamente significam falhas reparáveis.

Goracci e Ferrari (2011) publicaram uma revisão de literatura que resume os dados mais recentes e confiáveis sobre os sistemas de pinos. A busca foi limitada a artigos de revisão publicados nos últimos 10 anos em revistas odontológicas com fator de impacto. Documentos citados nos artigos de revisão, inicialmente recuperados, também foram incluídos, se significativos. Preservação de tecido dentário e adesão são consideradas como as condições mais eficazes para sucesso a longo prazo das restaurações pós-endodônticas. Cimentações adesivas reforçadas têm demonstrado taxas de sobrevivência relativamente mais satisfatórias em longos períodos de acompanhamento. A eficácia clínica de restaurações tem sido principal atributo de pinos de fibra, que reduz o risco de fraturas radiculares verticais. O tipo mais comum de falha ao usar pinos de fibra é o descolamento. A obtenção de adesão estável à dentina intra-radicular é mais desafiador do que a dentina coronal. Vários fatores relacionados ao tratamento endodôntico, a forma dos canais radiculares, o preparo para o pino, translucidez do pino, manipulação e a presa do cimento podem ter uma influência sobre o resultado do processo de cimentação. Os resultados mais confiáveis na cimentação de pino de fibra são obtidos por ataque ácido com enxague combinados com cimentos resinosos adesivos de cura dual. $\mathrm{O}$ uso de cimentos resinosos auto-adesivos também tem sido proposto. A simplificação é uma vantagem óbvia desses novos materiais. No entanto, a durabilidade de sua adesão ainda precisa ser verificada com estudos clínicos a longo prazo. Várias técnicas para pré-tratamento da superfície reforçada com compósitos foram testadas com o objetivo de melhorar a resistência de união nas interfaces pino-resina e pino-cimento. Em conclusão, as evidências disponíveis, valida o uso de pinos de fibra como uma alternativa aos pinos de metal, na restauração de dentes tratados endodonticamente. Ensaios clínicos a longo prazo são esperados para fortalecer ainda mais esta evidência.

De acordo com Manicardi et al. (2011), uma complicação comum durante a restauração de dentes severamente destruídos é a perda de dentina radicular coronal. Os autores avaliaram a influência de diferentes cimentos na interface adesiva da parede de raízes enfraquecidas reforçadas com resina e pinos de fibra. Sessenta caninos superiores foram utilizados, as coroas foram removidas, e a 
espessura da dentina foi reduzida. Os espécimes do grupo experimental foram distribuídos em quatro subgrupos $(n=10)$ de acordo com o material de preenchimento: gutapercha + cimento de Grossmann, gutapercha + AH Plus, gutapercha + Epiphany, e Resilon + Epiphany. No grupo controle negativo $(n=10)$, os canais não foram preenchidos. Após preparo para pino, as raízes foram restauradas com resina composta ativada pela luz através de pino de fibra translúcida. Após 24 horas, as amostras foram seccionadas transversalmente em $1 \mathrm{~mm}$ de espessura. Teste push-out e MEV de diferentes regiões foram realizados. Dados de push-out foram analisados usando Teste Tukey de comparações múltiplas. A porcentagem de tipo de falha foi calculado Dados de MEV foram comparados por Friedman e Kruskal-Wallis $(\alpha=0,05)$. A resistência de união foi significativamente maior no grupo controle negativo em comparação com os outros grupos $(P<0,05)$. Em todos os grupos, o tipo mais freqüente de falha foi adesiva. No geral, as regiões apical e média apresentaram uma menor densidade de tags de resina do que a região coronal $(P<0,05)$. Os autores concluíram que a resistência de união push-out não foi afetada pelo cimento ou região.

Nothdurft et al. (2011), utilizando dentes bovinos, relataram que as amostras fraturaram em cargas de falha de $371 \mathrm{~N}$ (RelyX Unicem, testes de fadiga) a $494 \mathrm{~N}$ (KetacCem). Comparando os diferentes modos de cimentação, valores semelhantes para a carga de fratura podem ser encontrados antes do ensaio de fadiga. Após o envelhecimento artificial, espécimes restaurados com pinos cimentados convencionalmente, mostraram estatisticamente maiores cargas de fratura que os espécimes cimentados adesivamente (Panavia: $p=0,003$; RelyX Unicem, $p=$ $0,021)$. As raízes restauradas com pinos cimentados convencionalmente não revelou queda na resistência à fratura após fadiga. A diferença entre as cargas de fratura antes e depois do envelhecimento artificial não foi estatisticamente significativa para qualquer grupo. 


\section{PROPOSIÇÃO}

O objetivo do presente estudo foi avaliar, ex vivo, por meio da força de tração, a influência do tratamento dentinário com laser Er:YAG associado ou não ao condicionamento ácido, na adesividade da resina composta fotopolimerizável utilizada no reforço de raízes fragilizadas. 



\section{MATERIAL E MÉTODO}

\section{Aspectos éticos}

Este estudo foi desenvolvido após ser submetido e aprovado pelo Comitê de Ética em Pesquisa da Faculdade de Odontologia de Ribeirão Preto (Processo $n^{\circ}$ 2011.1.374.58.2) (ANEXO A).

\section{Seleção dos dentes}

Foram utilizados 50 caninos superiores humanos, provenientes do banco de dentes da Faculdade de Odontologia de Ribeirão Preto da Universidade de São Paulo - FORP USP, os quais apresentavam raízes com forma, comprimento e diâmetro mais próximos entre si. Isto é, por meio do paquímetro Digital (Digit CAL S M, Tesa, Swiss), selecionou-se aqueles que pudessem compor uma amostra mais homogênea.

Os dentes selecionados $(n=50)$ foram limpos com curetas periodontais SM 17/18 (Hu-Friedy, Rio de Janeiro, RJ, Brasil), e jato de bicarbonato, ar/água Jet-Sonic (Gnatus, Ribeirão Preto, SP, Brasil) e mantidos em solução de timol $0,1 \%$ até o momento do uso. 


\section{Preparo das raízes}

Definida a seleção dos dentes, os mesmos foram seccionados transversalmente por meio de discos de carborundum (SS White Company, Philadelphia, USA), montado em peça de mão com velocidade de 20.000 rpm (Dabi Atlante, Ribeirão Preto, SP, Brasil), sob refrigeração ar/água, com o propósito de separar as porções radiculares com diâmetros na região cervical aproximadamente iguais.

\section{Obtenção dos corpos de prova}

Foram confeccionados sulcos perperdiculares ao longo eixo do dente com disco de carborundum, nas superfícies vestibular e lingual, com o objetivo de proporcionar retenção quando da inclusão das raízes em resina acrílica.

As raízes foram centralizadas com auxílio de cera utilidade Wilson (Polidental, São Paulo, SP, Brasil) em uma matriz desmontável de alumínio com formato de retângulo, dividida em 5 compartimentos de seção quadrada (Figura 1B).

A seguir, resina acrílica auto-polimerizável incolor Jet (Clássico, São Paulo, Brasil) foi vertida em etapas, evitando-se assim, a formação de bolhas e superaquecimento durante sua reação de polimerização, incluindo as raízes, com exceção do remanescente cervical de $3 \mathrm{~mm}$ (Figura 1C). 


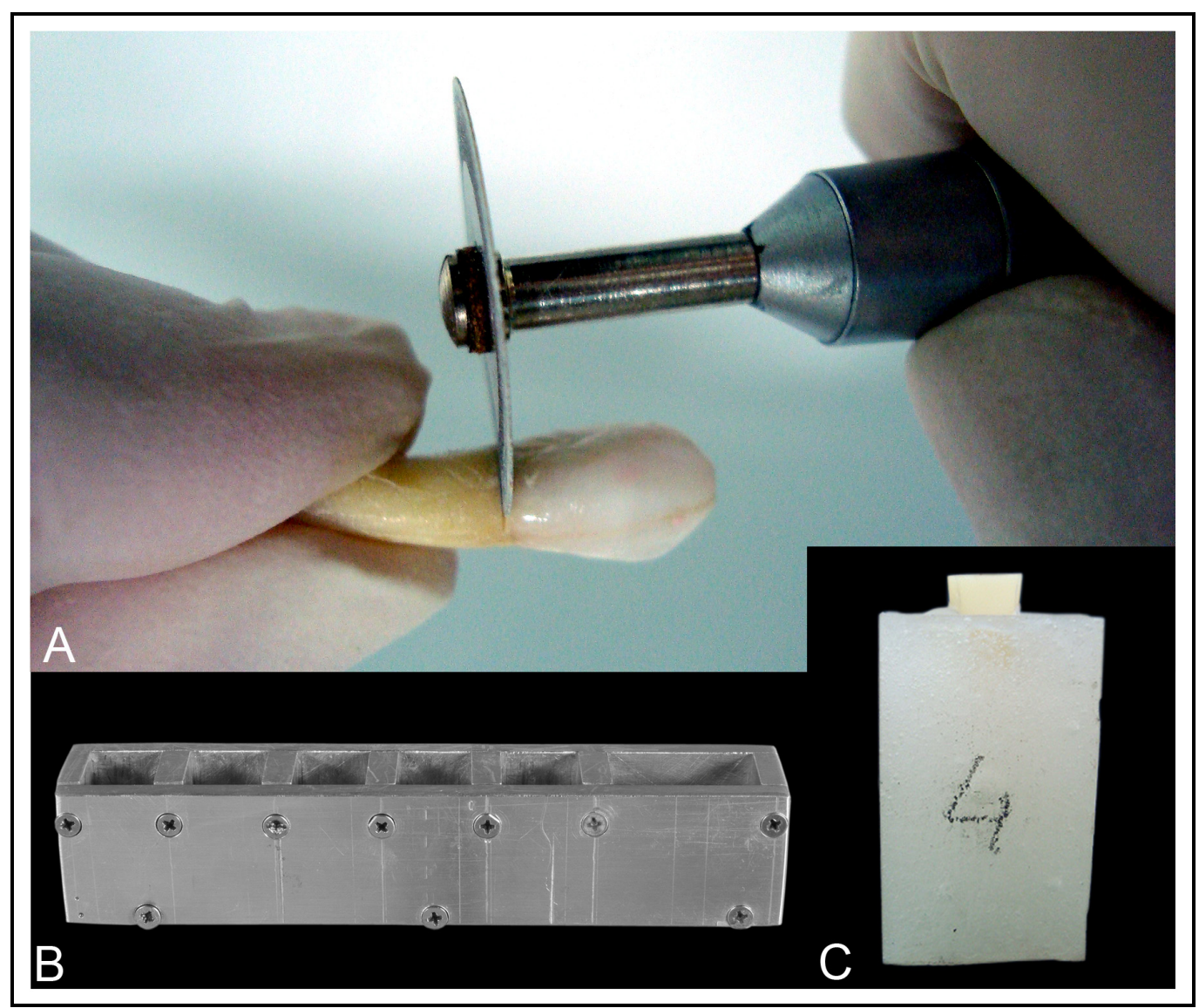

Figura 1. A) secção transversal após padronização do diâmetro cervical, B) Matriz desmontável de alumínio; C) raiz incluída em resina com exceção do remanescente cervical de $3 \mathrm{~mm}$.

\section{Fragilização das raízes}

Todos os corpos de prova receberam preparo de fragilização, utilizandose a seqüência de brocas 730PM; 720PM e 718PM (Figura 2A) (KG-Sorensen, São Paulo, SP, Brasil), nas extensões de 6, 7 e 8 milímetros, respectivamente. Os preparos foram realizados em baixa rotação com peça reta (Dabi Atlante, Ribeirão Preto, SP, Brasil) acoplada a um paralelômetro (Bioart, São Carlos, SP, Brasil) (Figuras 2B e 2C). Ao término de cada preparo, o canal era irrigado com $10 \mathrm{ml}$ de água destilada e deionizada para remoção de resíduos provenientes do desgaste. 


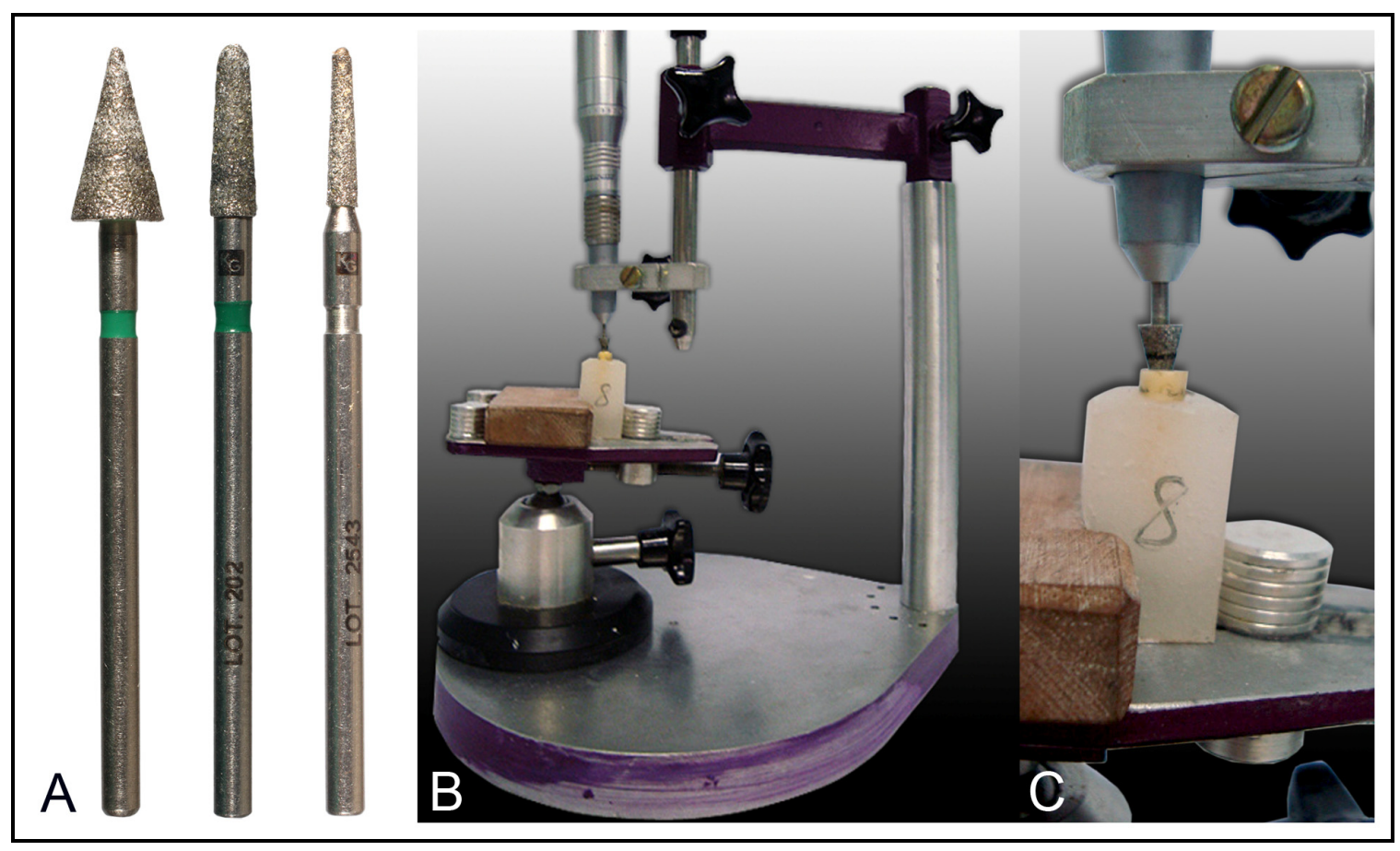

Figura 2. A) Brocas 730PM; 720PM e 718PM utilizadas no experimento; B) peça reta acoplada ao paralelômetro para fragilização. C) Vista aproximada do processo de fragilização.

\section{Tratamento endodôntico}

Após a fragilização, as raízes foram submetidas ao tratamento endodôntico de acordo com a Técnica Free Tip Preparation com os instrumentos rotatórios HERO 642 (MicroMega, Besançon, França), o preparo foi direcionado apenas ao remanescente radicular não tocado durante a fragilização, mantendo o comprimento de trabalho a 1 milímetro $(\mathrm{mm})$ do forame apical. Para acionar os instrumentos rotatórios foi utilizado o motor Endo Mate DT (NSK, Nakanishi Inc.,Japão), com velocidade de 300 rpm.

A cada troca de instrumento o canal foi irrigado com $2 \mathrm{ml}$ de hipoclorito de sódio a $2 \%$, aspirado e inundado com EDTA a $17 \%$, e irrigação final com 10 mililitros de água destilada e deionizada, seguido da secagem por meio da aspiração com capilary tips (Ultradent, South Jordan, EUA), e cones de papel absorvente (Dentsply-Herpo, Petrópolis, RJ, Brasil), compatíveis com o diâmetro cirúrgico do canal radicular no comprimento de trabalho.

Na seqüência, os canais foram obturados por meio da técnica de de Mc Spadden modificada com cones de guta percha (Tanari, Manacapuru, AM, Brasil) e cimento endodôntico AH Plus (Dentsply-Brasil, Petrópolis, RJ, Brasil). Com a 
intenção de obturar apenas a região não fragilizada, antecedendo o uso do compactador, após a colocação dos cones principal pré-selecionado com cimento e um acessório, era realizado um corte dos cones no nível da base cervical da raiz, por meio de instrumento hollenback (Duflex, Rio de Janeiro - Brasil) aquecido.

Em seguida, com o condensador de Paiva (Duflex, Rio de Janeiro, Brasil) aquecido, foi efetuado o corte do remanescente de guta-percha intraradicular no espaço de $8 \mathrm{~mm}$ (BRAGA et al. 2006). Os espaços preparados foram limpos por meio de pedaços de esponja de nylon embebidos em álcool, e posteriormente secos com o mesmo tipo de esponja, sem álcool, e ar. A cavidade foi vedada com uma porção de guta percha e cimento provisório Citodur (Dorident, Wien, Áustria), até a fase seguinte.

Os espécimes foram colocados em estufa à $37^{\circ} \mathrm{C}$ e $100 \%$ umidade por 72 horas, para o endurecimento do cimento AH Plus.

\section{Tratamento dentinário}

Para a fase do tratamento dentinário, os espécimes foram divididos aleatoriamente em cinco grupos $(n=10)$, que receberam diferentes tratamentos, a saber:

Grupo I - Ácido fosfórico 37\% (30 segundos) ;

Grupo II - Irradiação com laser de Er:YAG $10 \mathrm{~Hz}, 300$ mJ/pulso;

Grupo III - Irradiação com laser de Er:YAG 10 Hz, 300 mJ/pulso e ácido fosfórico $37 \%$ ( 30 segundos);

Grupo IV - Irradiação com laser Er:YAG 10 Hz, 500 mJ/pulso;

Grupo V - irradiação com laser Er:YAG $10 \mathrm{~Hz}, 500 \mathrm{~mJ} /$ pulso e ácido fosfórico $37 \%$ (30 segundos).

O equipamento laser utilizado neste estudo foi o Opus 20 (Opus20, OpusDent, Tel-Aviv, Israel) com comprimento de onda de 2,94 $\mu \mathrm{m}$, o laser foi aplicado através de uma fibra , cujo diâmetro foi de 1,35mm.(Figura 3). 


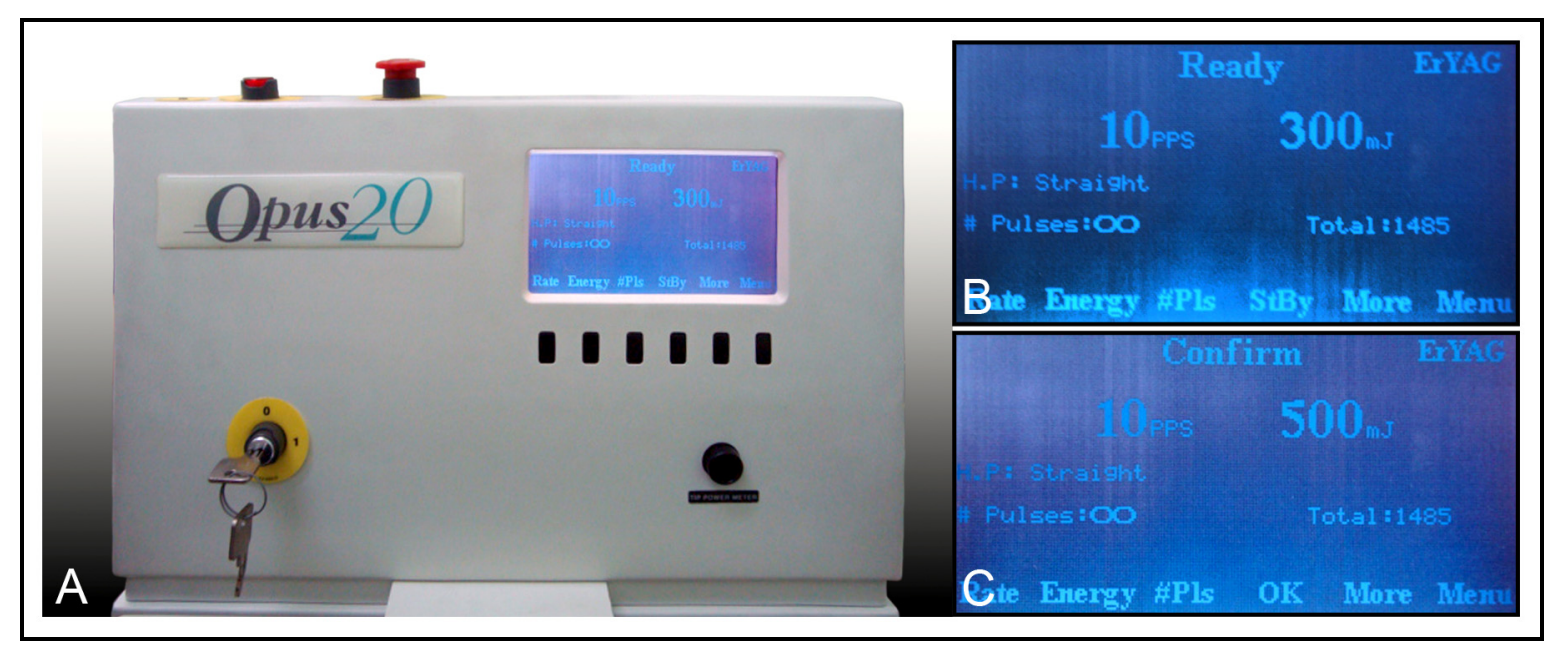

Figura 3. A) equipamento laser Opus 20; B e C) Parâmetros utilizados.

A irradiação laser foi aplicada por 16 segundos em cada raiz. Iniciou-se o processo com a ponta do laser colocada na extremidade cervical do canal radicular, e após acionado o dispositivo, com movimento helicoidal aplicava-se a irradiação em toda a extensão das paredes fragilizadas em direção apical, retornando em seguida, ao terço cervical com velocidade aproximada de $1 \mathrm{~mm} / \mathrm{s}$. O movimento de ida e volta ao longo das paredes dentinárias fragilizadas era realizado uma vez para cada raiz, com a ponta sempre em contato com essas paredes (Figuras 4A e 4B). 


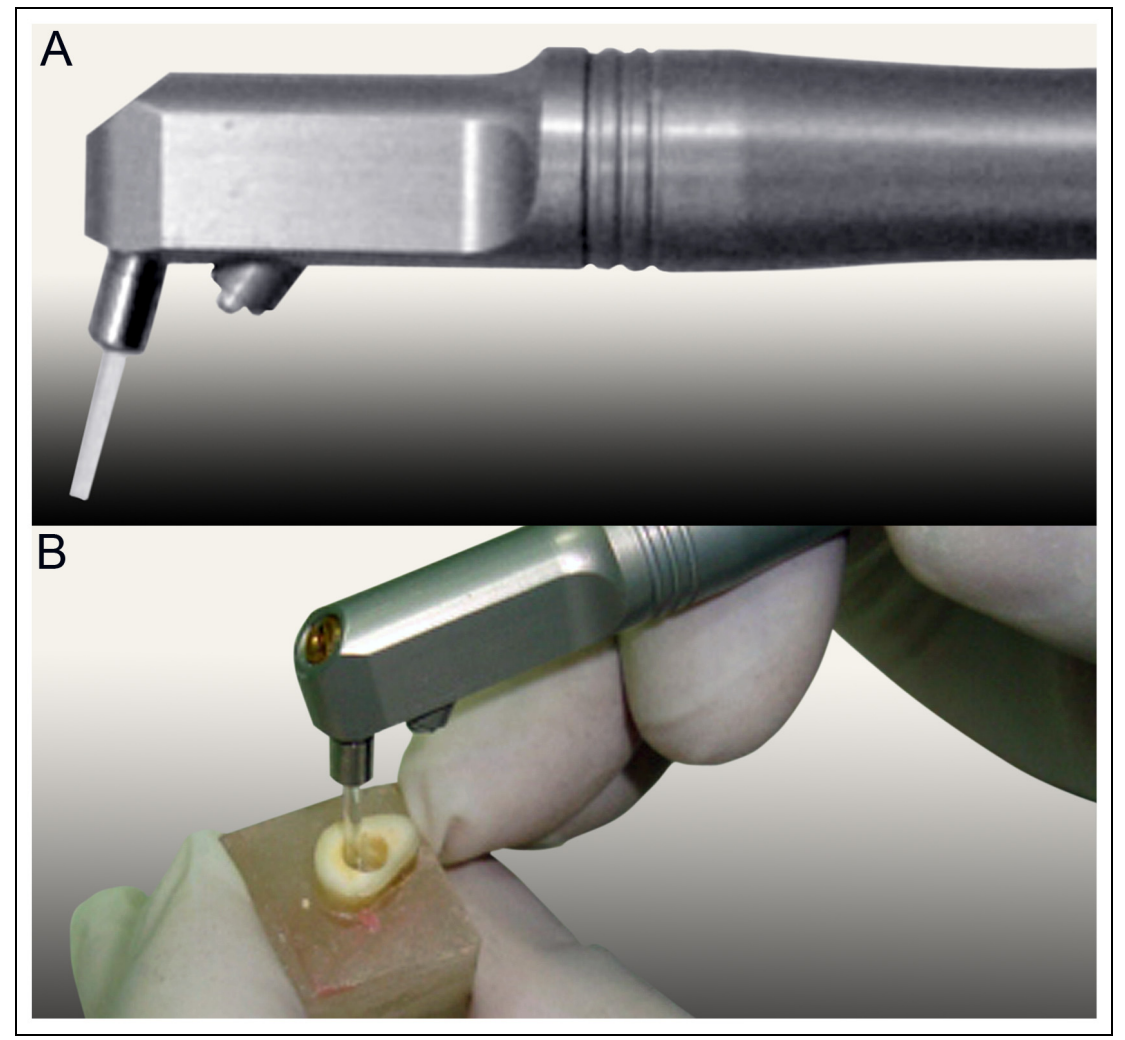

Figura 4. A) Ponta de fibra do Laser Er:YAG; B) Irradiação Laser sendo aplicada no interior da dentina fragilizada.

Tabela 1 - Parâmetros utilizados para a irradiação dos espécimes.

\begin{tabular}{lllllll}
\hline Laser & $\begin{array}{l}\text { Potêncial } \\
\text { Energia }\end{array}$ & $\begin{array}{l}\text { Duração de } \\
\text { pulso }\end{array}$ & $\begin{array}{l}\text { Taxa } \\
\text { repetição }\end{array}$ & $\begin{array}{l}\text { de } \\
\text { irradiação }\end{array}$ & $\begin{array}{l}\text { de } \\
\text { de onda }\end{array}$ \\
\hline Er:YAG & $300 \mathrm{~mJ}$ & $1 \mathrm{~mm} / \mathrm{s}$ & $10 \mathrm{~Hz}$ & contato & $2,94 \mu \mathrm{m}$ \\
Er:YAG & $500 \mathrm{~mJ}$ & $1 \mathrm{~mm} / \mathrm{s}$ & $10 \mathrm{~Hz}$ & contato & $2,94 \mu \mathrm{m}$
\end{tabular}

\section{Reforço Radicular}

As raízes fragilizadas receberam reforço intra-radicular por meio do uso de sistema adesivo, composto por primer e adesivo (Adper ${ }^{\mathrm{TM}}$ Scotchbond ${ }^{\mathrm{TM}}$ MultiPurpose, 3M), resina composta fotopolimerizável (Filtek Z250, 3M, Brasil), e pino fototransmissor (White post DC \#3, FGM, Joinville, SC, Brasil) (Figura 5A). 


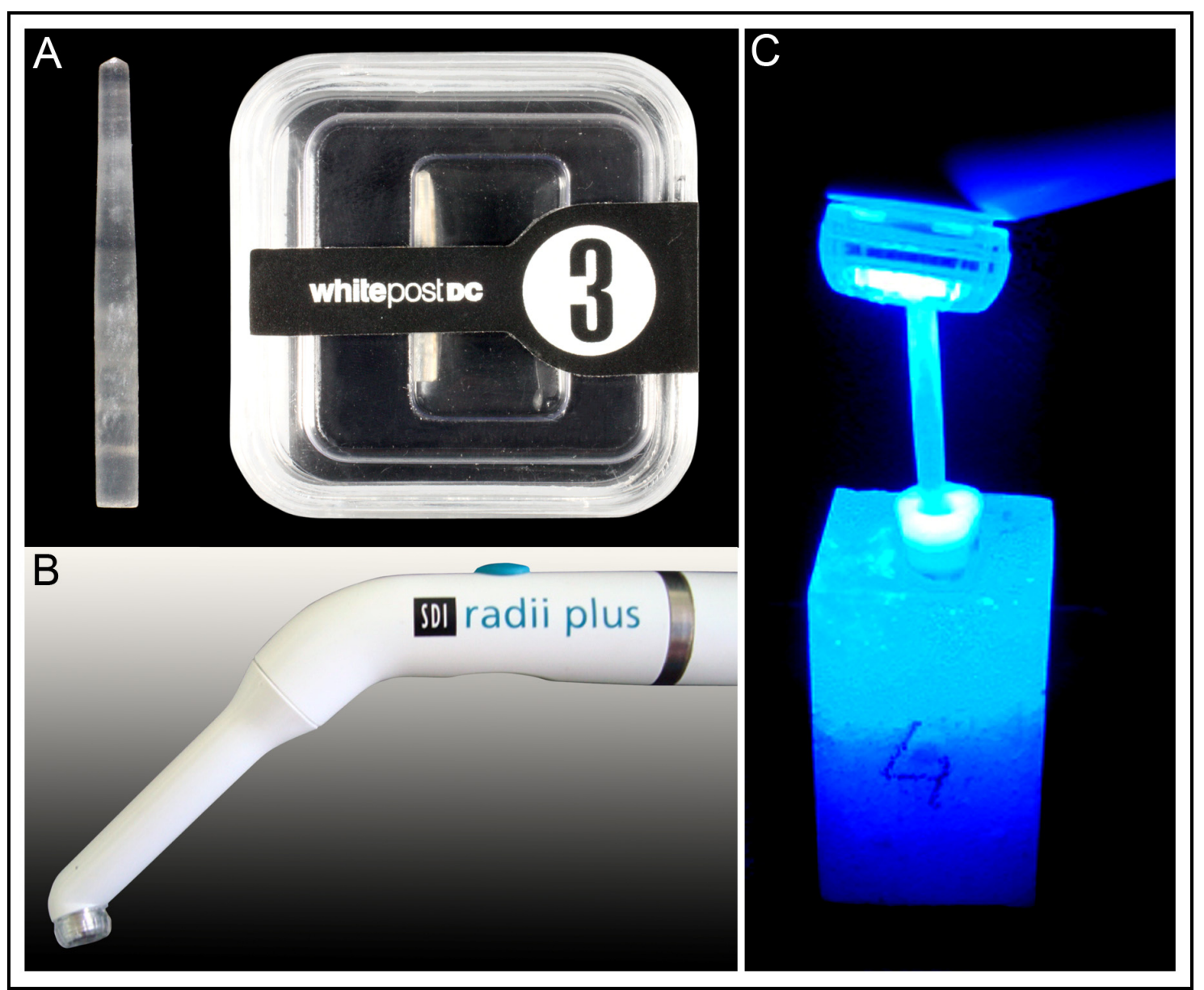

Figura 5. A) Pino fototransmissor; B) Aparelho fotopolimerizador Led Radii Plus de alta intensidade; C) Polimerização da resina composta através do pino fototransmissor.

Após o tratamento dentinário, os espécimes dos grupos I, III e V, receberam ataque ácido, com ácido fosfórico à 37\% (Scotchbond etchant, a $3 \mathrm{M}$ ESPE, St. Paul, MN, EUA) por 30 segundos, posteriormente foram lavados com água destilada e deionizada e secos com jatos de ar. O processo de reforço foi iniciado aplicando o sistema adesivo pela técnica do microbrush (FONSECA, 2006) e polimerizando com o pino fototransmissor por 1 minuto por meio de um aparelho fotopolimerizador Led Radii Plus, de alta intensidade $-1.500 \mathrm{~mW} / \mathrm{cm}^{2}$ (SDI, Austrália) (Figura 5B), em todos os grupos. O pino foi removido e o espaço radicular preenchido com resina composta fotopolimerizável.

Para a fotopolimerização da resina, era utilizado novamente o pino plástico fototransmissor, agora com uma fina camada de vaselina, que ao ser inserido de forma centralizada na massa resinosa até tocar o fundo da cavidade, recebia a luz do mesmo aparelho fotopolimerizador Led por, por um tempo de um minuto (Figura $5 \mathrm{C}$ ). Em seguida, com auxílio de um alicate, o pino plástico foi 
removido do interior da raiz, demarcando o espaço para a cimentação do pino metálico Reforpost II ( Figura 6A).

O espaço era lavado com $10 \mathrm{ml}$ de água destilada e deionizada com pincel microbrush, para remoção de resíduos da vaselina e seco com jatos de ar.

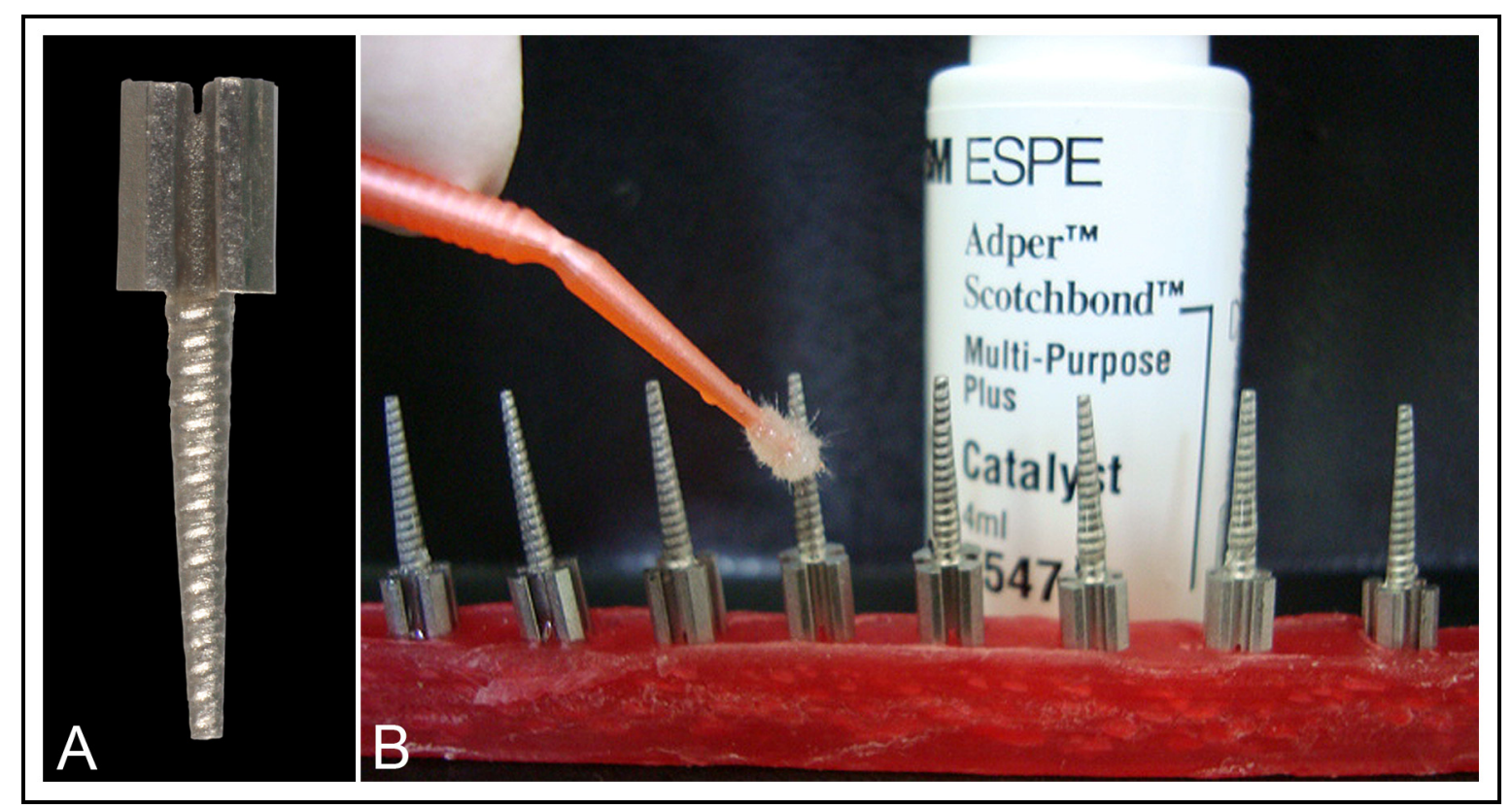

Figura 6. A) Pino metálico Reforpost II n³; B) Aplicação do catalizador.

\section{Cimentação dos pinos com RelyX Unicem}

Os pinos foram previamente limpos com gaze embebido em álcool absoluto, para remoção de possíveis resíduos aderidos, e em seguida com microbrush foi aplicado Catalizador (Adper ${ }^{\mathrm{TM}}$ Scotchbond ${ }^{\mathrm{TM}}$ Multi-Purpose Plus) (Figura 6B). Depois de 60 segundos, um jato de ar foi aplicado por 5 segundos.

Para a cimentação dos pinos metálicos foi utilizado o cimento resinoso RelyX Unicem, que é um cimento resinoso auto adesivo de dupla polimerização.

O cimento resinoso foi manipulado em placa de vidro de acordo com o manual do fabricante. O cimento foi introduzido no interior do espaço promovido pelo pino fototransmissor com o auxílio de uma lima $\mathrm{K} \# 40$ e, em seguida, o pino metálico era inserido também impregnado com o cimento. 
A fotoativação do cimento foi realizada por meio do fotopolimerizador por 15 segundos em cada face (vestibular, lingual e proximais) em direção à linha de cimentação, perfazendo um total de 1 minuto de ativação por luz.

Os corpos de prova com os pinos cimentados (Figura 7A e 7B) foram então armazenados em estufa à $37^{\circ} \mathrm{C}$ e $100 \%$ umidade por 24 horas.

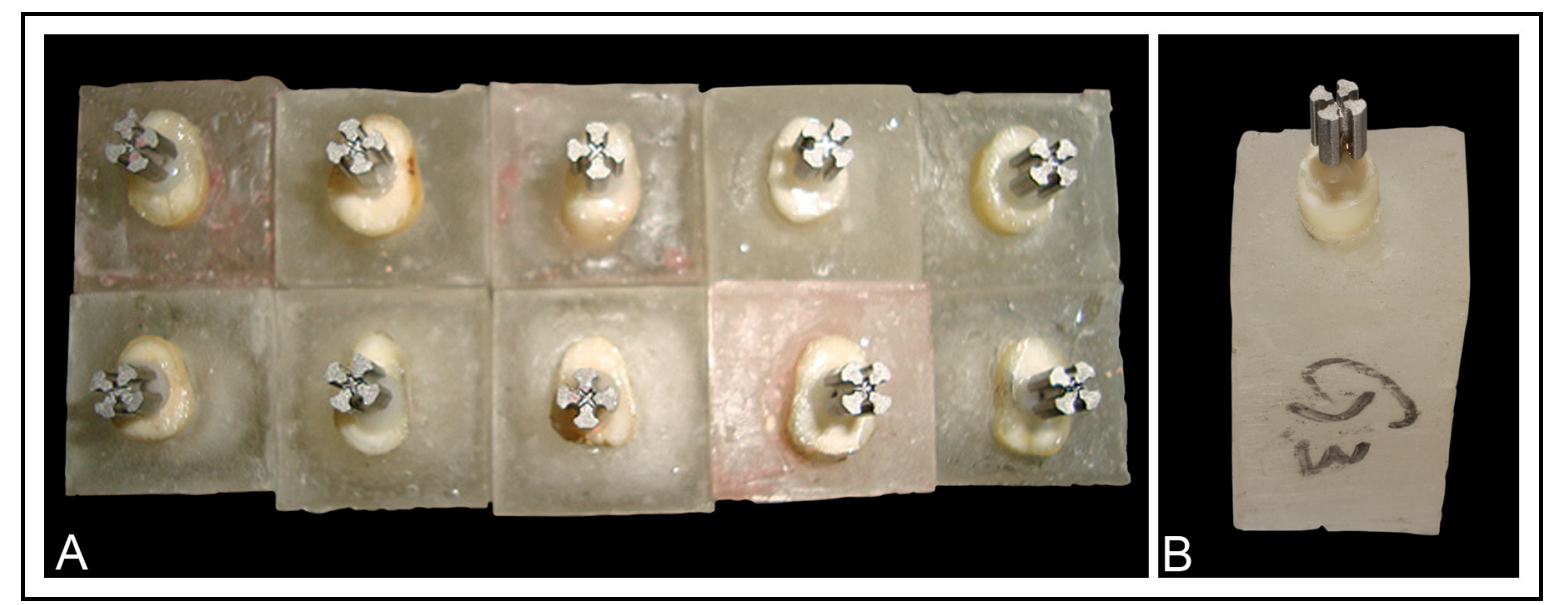

Figura 7. A) Vista oclusal dos corpos de prova de um grupo; B) Vista palatina de um corpo de prova com a identificação do grupo que pertence.

\section{Teste de Tração}

Os corpos de prova foram, então, submetidos ao teste de Tração na Máquina Universal de Ensaios - INSTRON 4444 (Instron Corporation, CantonMassachusetts, USA), (Figuras 8A, 8B e 8C), utilizando-se um dispositivo especialmente desenvolvido para padronizar o posicionamento do corpo de prova, minimizando as forças laterais e mantendo a tração no sentido do longo eixo do dente, com velocidade de $1 \mathrm{~mm} / \mathrm{min}$.

Após o deslocamento do pino intra-radicular o valor da força máxima, registrado pela máquina em $\mathrm{kN}$. foi anotado. Posteriormente, por meio de uma formula especifica (Quadro I), o valor foi transformado em tensão em MPa. O arquivo de dados resultantes da transformação foi submetido à análise estatística. 


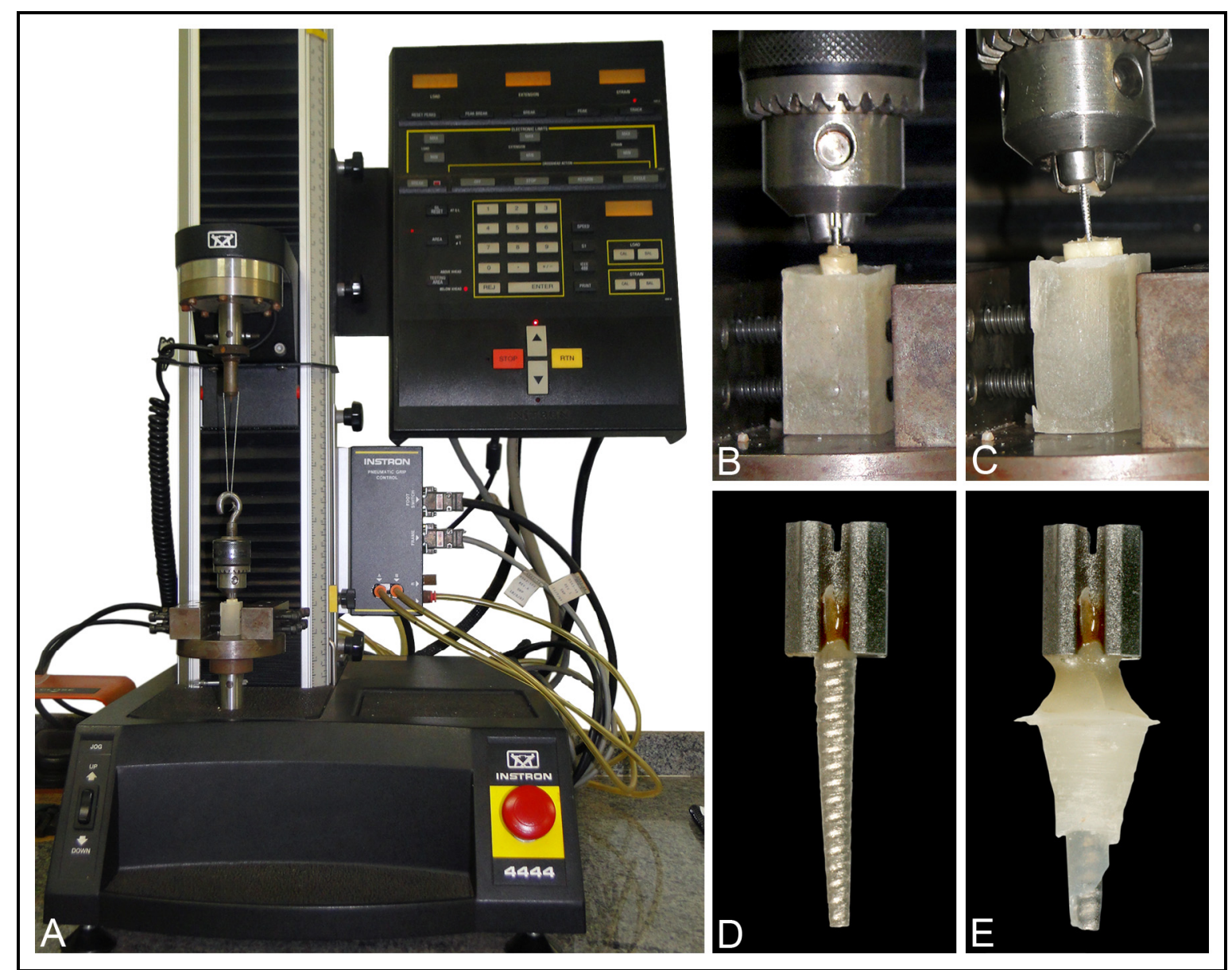

Figura 8. A) Máquina Universal de ensaios - Instron 4444; B) e C) Tracionamento do pino; D) Pino metálico após deslocamento; E) Conjunto de pino metálico e reforço radicular em resina composta após deslocamento. 



\section{RESULTADOS}

Os dados experimentais deste trabalho consistiram em cinquenta valores numéricos de resistência à tração expressos em $\mathrm{KN}$. Os resultados da força máxima necessária para o deslocamento dos retentores intra radiculares obtidos nos ensaios de tração podem ser observados na Tabela II.

Tabela II - Valores da força de tração, em kN, necessária para o deslocamento dos retentores intra radiculares.

\begin{tabular}{ccccc}
\hline $\begin{array}{c}\text { Grupo I } \\
\text { Controle } \\
\text { sem laser } \\
\text { Com ácido }\end{array}$ & $\begin{array}{c}\text { Grupo II } \\
\text { Er:YAG } \\
\text { 300mJ } \\
\text { Sem ácido }\end{array}$ & $\begin{array}{c}\text { Grupo III - } \\
\text { Er:YAG 300mJ }\end{array}$ & $\begin{array}{c}\text { Grupo IV } \\
\text { Er:YAG 500mJ }\end{array}$ & $\begin{array}{c}\text { Grupo V } \\
\text { Er:YAG 500mJ }\end{array}$ \\
\hline 0,1837 & 0,1302 & 0,0612 & Sem ácido & Com ácido \\
0,2330 & 0,0657 & 0,2818 & 0,1361 & 0,1998 \\
0,2217 & 0,0785 & 0,0815 & 0,1195 & 0,1637 \\
0,1796 & 0,0898 & 0,2318 & 0,1431 & 0,1451 \\
0,3002 & 0,1689 & 0,2267 & 0,0725 & 0,0894 \\
0,2526 & 0,0582 & 0,1252 & 0,0342 & 0,1309 \\
0,3023 & 0,1352 & 0,2146 & 0,1051 & 0,1052 \\
0,2606 & 0,1480 & 0,0497 & 0,1129 & 0,1760 \\
0,2115 & 0,2063 & 0,1906 & 0,1750 & 0,0923 \\
0,1852 & 0,0413 & 0,1864 & 0,1895 & 0,1304 \\
$0,233 \pm 0,045$ & $0,112 \pm 0,054$ & $0,165 \pm 0,080$ & $0,115 \pm 0,048$ & $0,137 \pm 0,036$ \\
\hline
\end{tabular}


Observações:

GRUPO I e Grupo III - Em 90\% houve deslocamento do pino (união pino/resina)

GRUPO II - 100\% de deslocamento do reforço radicular (união resina/dentina)

GRUPO IV - 70\% de deslocamento do reforço radicular (união resina/dentina)

GRUPO V - Em 60\% houve deslocamento do pino (união pino/resina)

Após o teste de tração, foram calculadas as áreas da fragilização e do espaço preparado para o pino, para posterior cálculo da tensão.
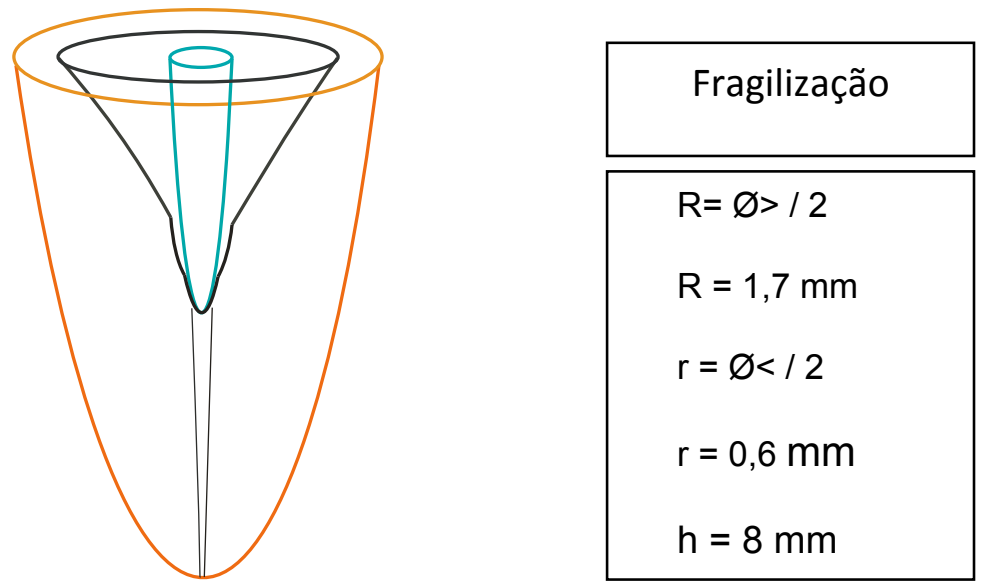

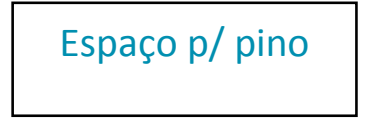

$R=\varnothing>/ 2$

$\mathrm{R}=0,89 \mathrm{~mm}$

$r=\varnothing</ 2$

$\mathrm{r}=0,6 \mathrm{~mm}$

$\mathrm{h}=8 \mathrm{~mm}$

Figura 9- Desenho esquemático da porção radicular, com área de fragilização (em preto) e espaço para pino (em azul), e suas respectivas medidas.

A tensão sobre a resistência de união (em $\mathrm{MPa}$ ) foi calculado usando a fórmula $\sigma=F / A$, onde $\sigma$ é a tensão a ser calculada, $F$ é a força máxima de ruptura do vínculo (em kN) e A é a área a ser calculada ( da fragilização e do reforço radicular) em $\mathrm{mm}$. Como a força é em $\mathrm{kN}$ os valores foram multiplicados por $10^{3}$.

Para cálculo da área foi utilizada a fórmula $A=\pi .(R>+r<)$. h, onde A é a área, $\pi$ é o valor $3,14, \mathrm{R}$ é o raio maior, $r$ é o raio menor e $\mathrm{h}$ é a altura.

Quando houve o deslocamento do reforço radicular, para cálculo da área foi utilizada a área da fragilização $(A=57,776)$, e quando houve deslocamento do pino foi calculada a área do reforço radicular $(A=37,4288)$.

Quadro I - Fórmulas utilizadas para cálculo de tensão, força e área:

$$
\begin{gathered}
\sigma=\mathbf{F} / \mathrm{A} \\
\mathbf{F}=\text { valor em kN x10 } \\
A=\pi \cdot(\mathrm{R}>+\mathbf{r}<) . \mathbf{h}
\end{gathered}
$$


Tabela III - Valores em MPa da Tensão após cálculo da área de deslocamento.

\begin{tabular}{ccccc}
\hline Grupo I & $\begin{array}{c}\text { Grupo II } \\
\text { Er:YAG } \\
\text { 300mJ } \\
\text { Sem ácido }\end{array}$ & $\begin{array}{c}\text { Grupo III - } \\
\text { Er:YAG } \\
300 \mathrm{~mJ} \\
\text { Com ácido }\end{array}$ & $\begin{array}{c}\text { Grupo IV } \\
\text { Er:YAG } \\
500 \mathrm{~mJ} \\
\text { Sem ácido }\end{array}$ & $\begin{array}{c}\text { Grupo V } \\
\text { Er:YAG } \\
500 \mathrm{~mJ} \\
\text { Com ácido }\end{array}$ \\
\hline 4.900 & 2.253 & 1.059 & 1.209 & 3.548 \\
6.225 & 1.137 & 7.528 & 2.355 & 2.487 \\
5.923 & 1.358 & 2.177 & 2.068 & 4.288 \\
3.108 & 1.554 & 6.193 & 2.476 & 3.876 \\
8.020 & 2.923 & 6.056 & 1.254 & 1.547 \\
6.748 & 1.007 & 3.345 & 0.591 & 3.497 \\
8.076 & 2.340 & 5.733 & 1.819 & 2.810 \\
4.515 & 2.561 & 1.327 & 3.016 & 4.702 \\
3.660 & 3.570 & 5.092 & 4.675 & 2.466 \\
4.948 & 0.714 & 4.980 & 5.062 & 3.483 \\
$5.61 \pm 1.69$ & $1.94 \pm 0.92$ & $4.35 \pm 2.23$ & $2.45 \pm 1.45$ & $3.26 \pm 0.94$ \\
\hline
\end{tabular}

Tabela IV - Cálculos para avaliação de normalidade na amostra.

\begin{tabular}{lrrrrr}
\hline coluna titulo & $\begin{array}{r}\text { Grupo A } \\
\text { grupo1 }\end{array}$ & $\begin{array}{r}\text { Grupo B } \\
\text { grupo2 }\end{array}$ & $\begin{array}{r}\text { Grupo C } \\
\text { grupo3 }\end{array}$ & $\begin{array}{r}\text { Grupo D } \\
\text { grupo4 }\end{array}$ & $\begin{array}{r}\text { Grupo E } \\
\text { grupo5 }\end{array}$ \\
\hline média & 5.6123 & 1.9417 & 4.349 & 2.4525 & 3.2704 \\
desvio padrão (SD) & 1.695 & 0.9293 & 2.235 & 1.456 & 0.9468 \\
tamanho amostra (N) & 10 & 10 & 10 & 10 & 10 \\
Erro da média padrão(SEM) & 0.5361 & 0.2939 & 0.7069 & 0.4604 & 0.2994 \\
Abaixo 95\% limite confiança & 4.400 & 1.277 & 2.750 & 1.411 & 2.593 \\
Acima 95\% limite confiança & 6.825 & 2.606 & 5.948 & 3.494 & 3.948 \\
Minimo & 3.108 & 0.7140 & 1.059 & 0.5910 & 1.547 \\
Mediano (50 por cento) & 5.436 & 1.904 & 5.036 & 2.212 & 3.490 \\
Máximo & 8.076 & 3.570 & 7.528 & 5.062 & 4.702 \\
teste Normalidade KS & 0.1524 & 0.1617 & 0.2111 & 0.1936 & 0.1888 \\
valor P teste Normalidade & $>0.10$ & $>0.10$ & $>0.10$ & $>0.10$ & $>0.10$ \\
Passou no teste de normalidade? & $\mathrm{sim}$ & $\mathrm{sim}$ & $\mathrm{sim}$ & $\mathrm{sim}$ & $\mathrm{sim}$ \\
\hline
\end{tabular}

Os dados foram submetidos a testes estatísticos preliminares e o cálculo dos parâmetros amostrais sugerem uma distribuição amostral normal.

A análise de variância (ANOVA) indicou que houve diferença estatistica extremamente significante $(p<0,0001)$. Variação entre as médias é significativamente maior do que o esperado por acaso. Como $\mathrm{P}<0,05$, há diferença entre os grupos, sendo realizado o Teste Tukey-Kramer de Comparações Múltiplas. 
Tabela V - Teste Tukey-Kramer de Comparações Múltiplas.

\begin{tabular}{lccc}
\hline Comparação & Diferença média & $\mathrm{q}$ & $\mathrm{P}$ value \\
\hline grupo1 vs grupo2 & 3.671 & 7.572 & *** $\mathrm{P}<0.001$ \\
grupo1 vs grupo3 & 1.263 & 2.606 & $\mathrm{~ns} \mathrm{P}>0.05$ \\
grupo1 vs grupo4 & 3.160 & 6.518 & $* * * \mathrm{P}<0.001$ \\
grupo1 vs grupo5 & 2.342 & 4.831 & $* \mathrm{P}<0.05$ \\
grupo2 vs grupo3 & -2.407 & 4.966 & $* * \mathrm{P}<0.01$ \\
grupo2 vs grupo4 & -0.5108 & 1.054 & $\mathrm{~ns} \mathrm{P}>0.05$ \\
grupo2 vs grupo5 & -1.329 & 2.741 & $\mathrm{~ns} \mathrm{P}>0.05$ \\
grupo3 vs grupo4 & 1.897 & 3.912 & $\mathrm{~ns} \mathrm{P}>0.05$ \\
grupo3 vs grupo5 & 1.079 & 2.225 & $\mathrm{~ns} \mathrm{P}>0.05$ \\
grupo4 vs grupo5 & -0.8179 & 1.687 & $\mathrm{~ns} \mathrm{P}>0.05$ \\
\hline
\end{tabular}

O grupo I (grupo controle), que recebeu tratamento com ácido sem irradiação laser, apresentou os maiores valores de resistência à tração, sendo estatisticamente semelhante ao grupo III (espécimes que receberam tratamento de laser Er:YAG $300 \mathrm{~mJ}-10 \mathrm{~Hz}$ e condicionamento ácido) e diferente estatisticamente dos grupos II, IV e V.

O grupo III (espécimes irradiados com laser de Er:YAG $300 \mathrm{~mJ}-10 \mathrm{~Hz}$ e tratados com condicionamento ácido), não apresentou diferença estatisticamente significante quando comparados aos grupos IV e V (espécimes irradiados com laser Er:YAG nos parâmetros de $500 \mathrm{~mJ}$ e $10 \mathrm{~Hz}$ sem e com condicionamento ácido respectivamente) .

O grupo II (espécimes irradiados com laser Er:YAG $300 \mathrm{~mJ}$ e $10 \mathrm{~Hz}$ sem condicionamento ácido), não apresentou diferença estatistica quando comparados aos grupos IV e V (espécimes irradiados com laser Er:YAG nos parâmetros de 500 $\mathrm{mJ}$ e $10 \mathrm{~Hz}$ sem e com condicionamento ácido).

\section{Gráfico I - Média e Desvio Padrão}

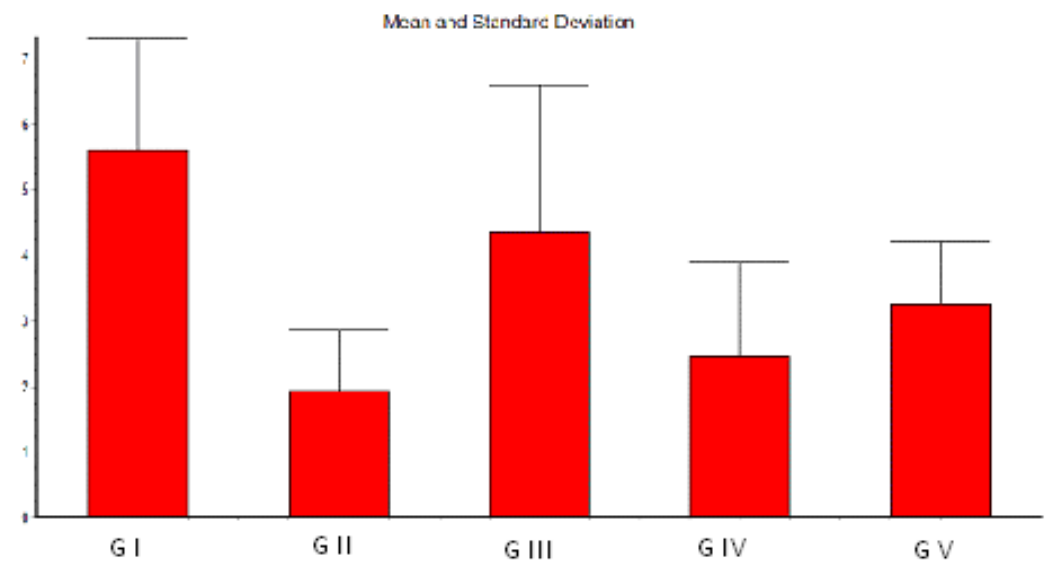




\section{DISCUSSÃO}

A preservação da estrutura dental é um dos fatores mais importantes a ser considerado para o tratamento e restauração de dentes tratados endodonticamente. Quando há perda de estrutura dental, devemos restaurar o elemento de maneira que se aproxime ao máximo da forma original.

Para se conseguir esta aproximação das condições naturais é indispensável que se conduza o planejamento embasado em duas condições fundamentais e necessárias para um sucesso final: quanto mais estrutura preservada, melhor a restauração, quanto mais próximas às propriedades mecânicas e biológicas dos materiais restauradores, melhor o desempenho da função dental. Esta abordagem, tendo como referência o dente hígido pode ser extensível aos dentes tratados endodonticamente em qualquer estágio de destruição ou fragilização estrutural em que eles se apresentem (COELHO, 2003).

Desta maneira, ao reabilitar raízes fragilizadas estruturalmente, devemos procurar materiais e métodos que promovam além da forma, a função do elemento dental. 
Diante disto, este trabalho buscou a reabilitação de raízes fragilizadas estruturalmente, visando definir qual a maneira de promover retenção do reforço radicular às paredes dentinárias dessas raízes.

Alguns aspectos em relação à metodologia utilizada merecem destaque para melhor entendimento. Para realização desta pesquisa foram utilizados cinquenta caninos superiores, por possuírem raiz longa e canal único. Este fato permitiu melhor padronização quanto ao diâmetro necessário na porção cervical, que proporcionasse a espessura aproximada de um milímetro de remanescente dentário após o desgaste da fragilização. Esta fragilização foi norteada por trabalhos existentes na literatura (MARTINS, 1995; SAUPE et al., 1996; GONÇALVES, 2006), que definiram como sendo uma espessura mínima de estrutura radicular remanescente em trabalhos que avaliaram a resistência à fratura.

Neste estudo, para todas as amostras, o comprimento da porção intra radicular do preparo para promover a fragilização foi padronizado em oito milímetros, e o diâmetro do preparo foi constante ao utilizar as mesmas brocas para esta finalidade, obedecendo a metodologia proposta por Gonçalves (2006).

Os parâmetros utilizados para aplicação do laser Er:YAG, bem como a não utilização de água, foram utilizados de acordo com pesquisa de Lee et al. em 2003, onde a utilização ou não de água nestes mesmos parâmetros mostraram resultados semelhantes em Microscopia Eletrônica de Varredura. A dentina humana irradiada com 300mJ apresentou um padrão semelhante de ablação e túbulos dentinários expostos independente ou não de ter spray de água.

Neste estudo a aplicação do laser como meio de preparo da parede dentinária foi realizada sem irrigação, por considerar também as observações de Sasaki et. al, (2002), de que a porosidade proporcionada pela utilização do laser sem irrigação não seria fator de contra-indicação, uma vez que esta porosidade poderia melhorar a adesão do material restaurador à parede dentinária.

O movimento helicoidal ao longo da superfície, com velocidade aproximada de $1 \mathrm{~mm} / \mathrm{s}$ durante 16 segundos, mantendo a ponta da fibra em contato com a dentina, e superfície radicular seca durante a aplicação do laser, bem como a utilização do silano no pino com microbrush, espera de 1 minuto, e secagem da superfície com jato de ar por 5 segundos, também foi preconizado por Garcia et al., 2010. 
Após o preparo da parede dentinária o reforço intra-radicular foi confeccionado em resina, selecionado com base nos vários trabalhos (STEELE, 1973; FREEDMAN, 1994; MARTINS, 1995; SAUPE et al., 1996; TJAN et al., 1997, OLIVEIRA JUNIOR, 1997; DE PAULA et al., 1998; MIRANZI et al., 2001; COELHO, 2003; HOU et al., 2003; MARCHI et al., 2003; ARUNPRADITKUL et al., 2004; SUMPANSIRIKUL et al., 2004; GONÇALVES, 2006), por minimizar os efeitos de estresse oclusal em dentes com tratamento endodôntico, consequentemente promover um efeito superior na resistência à compressão.

Cabe salientar, que em situações clínicas consegue-se fotopolimerizar uma resina em no máximo 2 a $3 \mathrm{~mm}$ de profundidade, devido ao efeito limitado da transiluminação na resina composta (LUI, 1994).

Contudo neste trabalho, utilizou-se de pinos fototransmissores que possibilitam minimizar o problema citado acima, pois se torna viável a fotopolimerização da resina por atingir pela trans-iluminação uma extensão maior, e polimerizar mais efetivamente a resina composta (GONÇALVES, 2006; MANICARDI et al., 2011). O ponto alto deste sistema é que, além de polimerizar a resina no interior do canal radicular, ele cria o espaço adequado para acomodar passivamente o pino metálico pré-fabricado (OLIVEIRA JUNIOR, 1997). Estas observações são confirmadas por Freedman et al., (1994) ao referirem que, com a utilização dos pinos transmissores de luz, consegue-se a eficácia na reabilitação intra-radicular, pois oferece ao clínico, oportunidade de criar uma estreita geometria para os pinos.

Foram utilizados em todos os espécimes pinos metálicos pré-fabricados de tamanho e forma semelhantes que pudessem ser cimentados passivamente no espaço proporcionado na resina pelo pino foto-transmissor (OLIVEIRA-JUNIOR, 1997), com a intenção de não causar stress sobre a resina, em extensão no remanescente dentinário (FREEDMAN et al., 1994; ARUNPRADITKUL et al., 2004).

$\mathrm{Na}$ ampla revisão da literatura levantada por Goracci; Ferrari (2011), sobre sistema de pinos, ficou evidente que o fator cimentante de escolha da maioria recai sobre os cimentos resinosos adesivos de cura dual, razão pela qual justifica a sua utilização neste trabalho.

Não foi intuito do presente trabalho uma avaliação da cimentação do pino, e sim a avaliação da resistência de união da resina composta fotopolimerizável às paredes dentinárias da raiz fragilizada. Este motivo influenciou na escolha de um pino metálico, pois raízes fragilizadas restauradas com pinos de fibra de vidro e 
reforço em resina composta apresentaram descolamento, sendo este o tipo mais comum de falha (GORACCI; FERRARI, 2011). A escolha do pino metálico e rosqueável, também, foi embasada no trabalho de Cohen et al. (1999), no qual relatam que este sistema de pinos apresenta aumento significante na força necessária para que ocorra a falha de retenção durante o tracionamento.

Entretanto se faz necessária uma observação inicial importante nos resultados aqui encontrados para os diferentes grupos, durante a realização do teste de tração. Nos Grupos I e III, o deslocamento do pino esteve presente na maioria dos espécimes, o que demonstra provavelmente que a falha tenha ocorrido entre 0 agente cimentante e a resina utilizada no reforço, uma vez que era possível também observar a presença do cimento nas ranhuras do pino rosqueável após o deslocamento. Consequentemente, podemos supor que para estes dois grupos, houve um melhor comportamento na união da resina composta utilizada para o reforço e a parede dentinária tratada, pois nos outros grupos o deslocamento ocorrido mais frequentemente foi do conjunto pino/resina, por falha na união resina/dentina provavelmente por um tratamento menos eficiente da parede dentinária.

Com a finalidade de avaliar essa resistência ao deslocamento dos materiais propostos como reforço de raiz fragilizada, foi utilizada a Máquina Universal de Ensaios, à velocidade de $1 \mathrm{~mm} / \mathrm{min}$, com base nos trabalhos de Fonseca et al., 2002; Braga et al., 2006.

Obtido os resultados, realmente verificou-se que o preparo da parede dentinária por meio do condicionamento ácido proporcionou maiores valores para o deslocamento, quando comparada aos grupos que não receberam este tratamento, isto é, promoveu melhor retenção do material utilizado como reforço da raiz fragilizada. Este resultado está parcialmente em concordância com os resultados obtidos por Ceballos et al. (2002) ao trabalharem em dentina superficial e profunda, onde encontraram também como resultado, que o condicionamento ácido sozinho obteve valores de resistência ao cisalhamento, significativamente maiores que os obtidos com a ablação a laser sozinho ou a combinação laser e ácido. Entretanto neste estudo, o grupo I (condicionamento ácido) foi estatisticamente semelhante ao grupo III (laser $300 \mathrm{~mJ}+$ condicionamento ácido), resultados estes corroborado por Sasaki et al. 2008, que ao trabalharem em superfície de esmalte afirmam a superioridade de resultado quando da associação entre laser Er:YAG e ácido 
fosfórico, e mencionam ser um recurso valioso para aumentar a resistência de união do sistema de resina composta e adesivo.

Portanto seria coerente afirmar que diferentes regiões, consequentemente diferentes estruturas podem influenciar na atuação dos meios utilizados para seu preparo, com a finalidade de proporcionar maior efetividade de adesão dos materiais utilizados.

Em raiz fragilizada a quantidade de dentina remanescente é pequena, portanto qualquer mudança estrutural poderia ser desfavorável na retenção do reforço utilizado. Marracini et al. (2006), ao estudar diferentes parâmetros de laser, com a finalidade de avaliar a força de adesão da resina composta aos tecidos dentários duros, relatam que uma das variáveis que podem influenciar na aderência é o aumento da temperatura produzido por um laser sobre estes tecidos durante a irradiação. Este aumento de temperatura pode alterar a matriz orgânica e como consequência o entrelaçamento de tecido e material restaurador pode interferir negativamente na eficiência da adesão. Este fato pode justificar também os resultados encontrados neste trabalho, onde menores valores de tensão para o deslocamento do material de preenchimento foram observados na maioria dos grupos que receberam irradiação, e mais negativamente nos grupos onde a potência de irradiação foi maior, que consequentemente gerou uma maior temperatura.

Outro fato importante observado é que, sendo o sistema adesivo comum em todos os grupos estudados, e o condicionamento ácido a variável, constatou-se que sua aplicação promoveu os melhores resultados, tanto no grupo controle (Grupo I) quanto naquele irradiado com menor potência (Grupo III), por apresentarem maiores valores de tensão para o deslocamento do reforço. Cumpre salientar, que para estes dois grupos houve deslocamento apenas do pino metálico na maioria dos corpos de prova, e para os demais grupos o deslocamento de maior ocorrência foi do conjunto pino/resina, que vem confirmar maior índice de falha na união resina/dentina, consequentemente, um tratamento menos eficiente das paredes dentinárias.

Frente às observações apresentadas torna-se evidente a viabilidade do reforço para raízes fragilizadas. Todavia fica claro também, a necessidade de novas pesquisas com emprego de diferentes materiais, analisados em situações diversas, que possibilitem minimizar cada vez mais as falhas existentes. 



\section{CONCLUSÕES}

Com base na metodologia utilizada e nos resultados obtidos, no que se refere à resistência à tração, é lícito concluir que:

1. O condicionamento ácido favoreceu a adesão da resina à parede dentinária, com exceção verificada quando da aplicação do laser de maior potência.

1.1. O condicionamento ácido, isoladamente e associado ao laser de menor potência, apresentou melhor resistência à tração;

2. A aplicação do laser de maior potência, associada ou não ao condicionamento ácido, apresentou comportamento semelhante à aplicação do laser de menor potência, associada ao condicionamento ácido.

2.1. A associação do laser de menor potência foi favorecida pelo condicionamento ácido das paredes dentinárias. 



\section{REFERÊNCIAS}

ALFREDO, E.; JUNIOR, J.R.; SILVA-SOUSA, Y.; SOBRINHO, L.O.; SAQUY, P.C.; SOUSA-NETO, M.D. Evaluation of retention of post-core system cemented with different materials on dentine surfaces treated with EDTA or Er:YAG laser irradiation. Photomed Laser Surg., v.23, n.1, p.36-40, 2005.

ARUNPRADITKOL, S.; SALIMEE, P.; DECHAUMPHAI, P. FEA of crown materials on stress distribution in flare-root-canal teeth. In: IADR/AADR/CADR 82nd GENERAL SESSION, 3095, Hawaii. 2004. Annals. Hawaii, IADR/ AADR/CADR, 2004.

BELL-RONNLOF, A.M.L.; LASSILA, L.V.J.; KANGASNEMI, I.; VALLITTU, P.K. Loadbearing capacity of human incisor restored with various fiber-reinforced composite posts. Dental Materials, v.27, n.6, p.e107-e115, 2011.

BITTER, K.; NOETZEL, J.; VOLK, C.; NEUMANN, K.; KIELBASSA, A.M. Bond Strength of Fiber Posts after the Application of Erbium:Yttrium-Aluminum-Garnet Laser Treatment and Gaseous Ozone to the Root Canal. J. Endod., v.34, n.3, p.306309, 2008.

BRAGA, N. M. A.; PAULINO, S. M.; ALFREDO, E.; SOUSA-NETO, M. D; VANSAN, L. P. Removal resistence of glass-fiber and metallic cast posts whit different lengths.

J. Oral Science., v.48, n.1, p.15-20, 2006.

\footnotetext{
${ }^{1}$ De acordo com a Associação Brasileira de Normas Técnicas NBR 6023
} 
BRUGNERA JÚNIOR, A.; GUERISOLI,D.M.Z.; MARCHESAN,M.A.; SPANÓ, .C.E.; PÉCORA, J.D. In vitro evaluation of smear removal by Er:YAG laser application with five different fiberotic tip with drawal techniques. Proc. Laser in Dent. IX, v.4950, p.188-194, 2003.

CARVALHO, M. R. O.; PEREIRA, L.C.G.; GARCIA, F. C. P.; MARQUESINI JR. L.; SILVA, S. M.A.; KUSSMAUL, A. P. M. Sistemas adesivos: fundamentos para compreensão de sua aplicação e desempenho em clínica. Biodonto., v.2, n.1, p.676, 2004.

CEBALLOS, L.; TOLEDANO, M.; OSORIO, R.; TAY, F.R.; MARSHALL, G.W.Bonding to Er-YAG-laser-treated Dentin. Journal of Dental Research, v.81, n.2, p. 119-122, 2002.

COELHO, F.I.S. Estudo in vitro do efeito da variação dos parâmetros dos lasers Er:YAG e ND:YAG sobre a dentina humana na adesividade cervical do cimento obturador de canais radiculares à base de resina epóxi. Ribeirão Preto, 2004. 94p. Dissertação (Mestrado). Faculdade de Odontologia - Universidade de Ribeirão Preto - UNAERP.

COHEN, B. I.; PAGNILLO, M.; MUSIKANT, B. L.; DEUTSCH, A. S. Comparison of the retentive and photoelastic properties of two prefabricated endodontic post systems. J. Oral Rehabil., v. 26, n. 6, p. 488-494, 1999.

DE PAULA, L. V.; ITO, L.; EDUARDO, C. P. Avaliação radiográfica do reforço intraradicular com utilização de resinas compostas fotopolimerizáveis. Rev. ABO Nac., v.6, n.1, p. 48-51, 1998.

FONSECA, T. S.; ALFREDO, E.; VANSAN, L. P.; SILVA, R. G.; SOUSA, Y. T. C. S.; SAQUY, P. C.; SOUSA-NETO, M. D. Retention of radicular posts varying the application technique of adhesive system and luting agent. Braz. Oral Res., v.20, n.4, p.347-352, 2006.

FREEDMAN, G.; NOVAC, I.M.; SEROTA, K.S.; GLASMAN, G.D. Intra-radicular rehabilitation: a clinical approach. Pract Periodontcs Aesthet Dent., v.6, n.5, p. 339, 1994.

GARCIA, L.D.F.R.; NAVES, L.Z.; CORRER-SOBRINHO, L.; CONSANI, S.; PIRESDE-SOUZA, F.D.C.P. Bond strength of a self-adhesive resinous cement to root dentin irradiated with a 980-nm diode laser. Acta Odontológica Scandinavica. v.68, n.3, p.171-179, 2010.

GIACHETTI, L.; GRANDINI, S.; CALAMAI, P.; FANTINI, G.; SCAMINACI RUSSO, D. Translucent fiber post cementation using light- and dual-curing adhesive techniques and a self-adhesive material: push-out test. J Dent. V.37, n.8, p. 638-42, 2009.

GODDER, B.; ZHUKOVSKY, L.; BIVONA, P. L.; EPELBOYM, D. Rehabilitation of thin-walled roots with light-activated composit resin: a case report. Compendium., v. 15, n. 1, p. 52-6, 1994. 
GONÇALVES, L. A. A.; VANSAN, L.P.; PAULINO, S.M.; SOUSA NETO, M. D. Fracture resistance of weakened roots restored with a transilluminating post and adhesive restorative materials. J. Prosthet. Dent., v.96, n.5, p.344-399, 2006.

GORACCI, C.; FERRARI, M. Current perspectives on post systems: a literature review. Aust Dent J. V.56, N.1, P. 77-83, 2011

HOU, R.; CHEN, X.; WU, J.; CHANG, H. The effect of rehabilitation of flared root canal on the fracture resistance of root and post-core system. Sichuan Da Xue Xue Bao yi Xue Ban.; v.34, n.3, p.510-2, 2003.

LEE, B-S.; HUNG, Y-L.; LAN, W-H. Compositional and morphological changes of human dentin after Er:YAG laser irradiation. Int. Congress Series, v.1248, p. 143152, 2003.

LUI, J.L. Cermet reinforcement of weakened endodontically treated root: a case report. Quintessence Int. v.23, n.8, p.533-8, 1992.

LUI, J.L. Composite resin reinforcement of flared canals using light-transmitting plastic posts. Quintessence Int., v.25, n.5, p.313-9, 1994.

MALLMANN, A.; JACQUES, L.B.; VALANDRO, L.F.; MUENCH,A. Microtensile bond strength of photoactivated and autopolymerized adhesive systems to root dentin using translucent and opaque fiber-reinforced composite posts. J. Prosthet. Dent., v.97, p.165-72, 2007.

MANICARDI, C.A.; VERSIANI, M.A.; SAQUY, P.C.; PÉCORA, J.D.; SOUSA-NETO, M.D. Influence of Filling Materials on the Bonding Interface of Thin-walled Roots Reinforced with Resin and Quartz Fiber Posts. Journal of Endodontics, v.37, n.4,p.531-537,2011.

MARCHI, G. M.; PAULINO, L. A.; PIMENTA, L. A.; DE LIMA, F. A. Effect of different filling materials in combination with intraradicular posts on the resistance to fracture of weakened roots. J. Oral. Rehabil., v. 30, n. 6, p. 623-9, 2003.

MARRACCINI, T. M.; BACHMANN, L.; WIGDOR, H. A.; WALSH JR., J. T.; TURBINO, M. L.; STABHOLZ, A.; ZEZELL, D. M. Enamel and dentin irradiation with $9.6 \mu \mathrm{m}$ CO2 and $2.94 \mu \mathrm{m}$ Er:YAG lasers: bond strength evaluation. Laser Phys. Lett., v.3, n.2, p.96-101, 2006.

MARTINS, L.R.M. Avaliação da resistência à fratura de raízes debilitadas reconstruídas morfologicamente com materiais adesivos. Piracicaba/SP, 1995. Tese (Livre-Docência - Dentística) - Faculdade de Odontologia de Piracicaba, Universidade de Campinas.

MCLEAN, J.W. Cermet cements. J. Amer. Dent. Ass. v.120, n.1, p.43-7, 1990.

MIRANZI, M. A. S.; FRONER. I. C.; MIRANZI, B. A. S..; VANSAN, L. P.; MIRANZI, A. J. S. Avaliação in vitro da resistência radicular à fratura utilizando pinos metálicos 
fundidos e pinos pré-fabricados Luminex. J. Brasil. Endo/Perio., v.2, n.7, p.311-6, 2001.

MOOSAVI, H., MALEKNEJAD, F.; KIMYAI, S. Fracture Resistance of Endodonticallytreated Teeth Restored Using Three Root-reinforcement Methods. J. Contemp.

Dent. Pract., v. 1, n. 9, p. 30-37, 2008.

MORITZ, A.; SCHOOP, U.; GOHARKHAY, K.; JAKOLITSCH, S.; KLUGER, W.; WERNISCH, J.; SPERR, W. The bactericidal effect of Nd:YAG, Ho:YAG, and Er:YAG laser irradiation in the root canal: an in vitro comparison. J. Clin. Laser Med Surg, v.17,n.4,p.161-4,1999.

NOTHDURFT, F.P.; SCHMITT, T.; RUPF, S.; POSPIECH, P.R. Influence of fatigue testing and cementation mode on the load-bearing capability of bovine incisors restored with crowns and FRC posts. Dent. Mater. J., v.30(1), p.109-114, 2011

OLIVEIRA JUNIOR, L. Retenção intra-radicular (Sistema Luminex) Rev. Assoc. Paul. Cir. Dent., São Paulo, v.51, n.1, 1997.

PÉCORA, J.D.; CAPELLI, A.; SEIXAS, F.H.; MARCHESAN, M.A.; GUERISOLI, D.M.Z. Biomecânica Rotatória: Realidade ou Futuro. Revista da Associação Paulista de Cirurgiões Dentistas, São Paulo, v.56, n.supl., p.04-06, 2002.

PERIN, F.M.; FRANÇA,S.C.; SILVA-SOUSA, Y.T.; ALFREDO, E.; SAQUY P.C.; ESTRELA, C.; SOUSA-NETO, M.D. Evaluation of the antimicrobial effect of Er:YAG laser irradiation versus $1 \%$ sodium hypochlorite irrigation for root canal disinfection.

Aust. Endod. J., v.30, n.1, p.20-2, 2004.

SASAKI, K. M.; AOKI, A.; MASUNO, H.; ICHINOSE, S.; YAMADA, S.; ISHIKAWA, I. Compositional analysis of root cementum and dentin after Er:YAG laser irradiation compared with $\mathrm{CO} 2$ lased and intact roots using Fourier transformed infrared spectroscopy. J. Periodont. Res., v.37, n.1, p.50-59, 2002.

SASAKI, L.H.; LOBO, P.D.C.; MORIYAMA, Y.; WATANABE, I. VILLAVERDE, A.B.; TANAKA, C.S.; MORIYAMA, E.H.; BRUGNERA, A. Tensile Bond Strength and SEM Analysis of Enamel Etched with Er:YAG Laser and Phosphoric Acid:A Comparative Study In Vitro. Braz. Dent. J., v.19, p.57-61, 2008.

SAUPE, A. W.; GLUSKIN, A. H.; RADKE, A. R. A comparative study of fracture resistance between morphologic dowel and cores and resin-reinforced dowel system in the intraradicular restoration of structurally compromised roots. Quintessence Int., v. 27, n. 7, p. 483-91, 1996.

STEELE, G. D. Reinforced composite resin foundation for endodontically treated teeth. J. Prosthet. Dent., v. 30, n. 5, p. 816-9, 1973.

SUMPANSIRIKUL, L.; SLIMEE, P. Fracture resistance of post and core restorations in flare-root-canal teeth. In: IADR/AADR/CADR 82nd GENERAL SESSION, 3094, Hawaii, 2004. Annals. Hawaii, IADR/AADR/CADR, 2004. 
TAKEDA, F.H.; HARASHIMA, T..; KIMURA, Y.; MATSUMOTO, K. Efficacy of Er:YAG laser irradiation in removing debris and smear layer on root canal walls. Journal of Endodontics, v.24, n.8, p.548-551, 1998.

TAKEDA, F. H.; HARASHIMA, T.; ETO, J. N.; KIMURA, Y.; MATSUMOTO, K. Effect of Er:YAG Laser treatment on the root canal walls of human teeth: a SEM study. Dent. Traumatol., v.14, n.6, p.270-3, 1998.

TEIXEIRA, C.S.; SILVA-SOUSA, Y.T.; SOUSA-NETO, M.D. Effects of light exposure time on composite resin hardness after root reinforcement using translucent fibre post. J. of Dentistry, v.36, n.7,p.520-528, 2008.

TEIXEIRA, C.S.; SILVA-SOUSA, Y.T.; SOUSA-NETO, M.D. Bond strength of fiber posts to weakened roots after resin restoration with different light-curing times. J. Endod., v.35, n.7, p.1034-1039, 2009.

TJAN, A. H.; SUN, J. C. Retention of Luminex post system, Oral Health, v. 87, n. 8, p. 31-5, 1997.

ZORBA, Y.O.; ERDEMIR, A.; TURKYILMAZ, A.; ELDENIZ A.U. Effects of Different Curing Units and Luting Agents on Push-out Bond Strength of Translucent Posts. J. Endod., v.36, n.9, p.1521-1525, 2010. 

ANEXO Anexo A - Aprovação no comitê de ética em pesquisa da faculdade de odontologia
de Ribeirão Preto

Ref. processo n: 2011.1.374.58.2

\section{UNIVERSIDADE DE SÃO PAULO}

Faculdade de Odontologia de Ribeirão Preto Comiace de Etica ema Pesquisa

OIATAC.CEP/16311/FORP-USP/26.04.2011

CALSIde

CAAE n.*0025.0.138.000.11

Senher Pesquisader:

Informamos que o Cemide de Etica em Pesquisa, em sua 119." Sessao, realizada em 14 de abril de 2011, aprovou o desenvolvimento do projeto de pesquisa envolvendo seres humancs, intitulado "Avalioģo da resistência a frafura de raizes fragilizadas tratedas com faser e reforçadas com resina composta"

Na oportunidade, lembramos da nesessidade de ser entregue, na secretaria do CEP, o Relatorio Final em 14/12/2011. com o respectivo formulario preenchido peio pesquisador responstwel.

Lembramos ainda que, quando da subenissao do relatorio a este Combe. quaisquer inclusoes ou modificap̧oes no projeto original deverao ser comunicadas e justificadas ao CEP, através do formulario supracitado.

FABRICIO DIAS DE CARVALHO

Secrotario "ad hoc" do Comilab do Etica em Pesquisa

Iino. St.

Prof. Dr. LUIZ PASCOAL VANSAN

Departamento de Odontologia Restauradora

desta Faculdade 